OPEN ACCESS

Edited by:

Robert Weissert,

University of Regensburg,

Germany

Reviewed by:

Arthur Liesz,

Ludwig-Maximilians-Universität

München, Germany

Anna Fogdell-Hahn,

Karolinska Institutet, Sweden

Andreas Meisel,

Charité Universitätsmedizin Berlin,

Germany

*Correspondence:

Mathias Gelderblom

m.gelderblom@uke.de

Specialty section: This article was submitted to

Multiple Sclerosis and

Neuroimmunology,

a section of the journal

Frontiers in Immunology

Received: 21 March 2017

Accepted: 10 July 2017

Published: 31 July 2017

Citation:

Thom V, Arumugam TV, Magnus T

and Gelderblom M (2017)

Therapeutic Potential of Intravenous Immunoglobulin in Acute Brain Injury.

Front. Immunol. 8:875.

doi: 10.3389/fimmu.2017.00875

\section{Therapeutic Potential of Intravenous Immunoglobulin in Acute Brain Injury}

\author{
Vivien Thom ${ }^{1}$, Thiruma V. Arumugam ${ }^{2}$, Tim Magnus ${ }^{1}$ and Mathias Gelderblom ${ }^{1 *}$ \\ ${ }^{1}$ Department of Neurology, University Medical Center Hamburg-Eppendorf, Hamburg, Germany, ${ }^{2}$ Department of Physiology, \\ Yong Loo Lin School of Medicine, National University of Singapore, Singapore, Singapore
}

Acute ischemic and traumatic injury of the central nervous system (CNS) is known to induce a cascade of inflammatory events that lead to secondary tissue damage. In particular, the sterile inflammatory response in stroke has been intensively investigated in the last decade, and numerous experimental studies demonstrated the neuroprotective potential of a targeted modulation of the immune system. Among the investigated immunomodulatory agents, intravenous immunoglobulin (IVIg) stand out due to their beneficial therapeutic potential in experimental stroke as well as several other experimental models of acute brain injuries, which are characterized by a rapidly evolving sterile inflammatory response, e.g., trauma, subarachnoid hemorrhage. IVIg are therapeutic preparations of polyclonal immunoglobulin $\mathrm{G}$, extracted from the plasma of thousands of donors. In clinical practice, IVIg are the treatment of choice for diverse autoimmune diseases and various mechanisms of action have been proposed. Only recently, several experimental studies implicated a therapeutic potential of IVIg even in models of acute CNS injury, and suggested that the immune system as well as neuronal cells can directly be targeted by IVIg. This review gives further insight into the role of secondary inflammation in acute brain injury with an emphasis on stroke and investigates the therapeutic potential of IVIg.

Keywords: acute brain injury, ischemic stroke, $F c \gamma$ receptors, sterile inflammation, treatment, intravenous immunoglobulin

\section{STERILE INFLAMMATION OF THE CENTRAL NERVOUS SYSTEM (CNS)}

Acute tissue damage is known to trigger a highly conserved cascade of inflammatory events. This inflammation is vital for the immediate response of the host to invasive pathogens in the settings of acute infection and it is characterized by a rapid recruitment of neutrophils to the side of injury. Similar to the inflammation in response to microorganisms, trauma, ischemia, or chemically induced tissue damage elicit a rapid inflammatory reaction. Due to the absence of microorganisms, this inflammatory response is termed "sterile inflammation" (1). Sterile inflammation shows several similarities with innate immune responses toward microorganisms. Both microbially induced inflammation and sterile inflammation are characterized by the initial generation of danger-associated patterns (DAMPs), production of inflammatory cytokines as well as chemokines, and subsequent recruitment of leukocytes. In the CNS, sterile inflammation is mainly associated with an exacerbation of the tissue damage, induced by the initial event. In the case of cerebral ischemia, inflammation of the peri-infarct area contributes to a subsequent growth of the infarct core in the first days and is thereby contributing to a secondary worsening of the neurological outcome (2). However, at later stages inflammation might also be important for the resolution of the tissue damage and long-term 
recovery, even though these processes are currently only poorly understood (3). In addition to inflammation associated with acute injuries, there is also convincing evidence for the importance of chronic inflammatory processes in degenerative diseases of the brain, including Parkinson's and Alzheimers disease (4).

\section{Development and Consequences of Inflammation in Stroke Pathophysiology of Cerebral Ischemia}

Ischemic stroke is a devastating disease and represents the most common cause of long-term disability in adults as well as the third leading cause of death in the western world. Due to the improving management of risk factors, the incidence of stroke in the western world has decreased over the past decades. Nevertheless, the prevalence has risen based on a reduced mortality (5). This shift will probably become even more prominent in the future due to improved treatment, but particularly on the basis of an increase in life expectancy and a net aging population. Considering the annual direct and indirect costs emerging for the treatment of stroke patients an enormous economic burden is emerging. Typically, an occlusion of a major artery, leading to disruption of blood supply, causes an ischemic stroke and the only treatment option is the early restoration of blood flow. Available treatment strategies include drug-induced thrombolysis as well as endovascular treatment with thrombectomy, but the major limiting factor is the onset-to-treatment time.

Focal disruption of cerebral circulation (ischemia) as well as the subsequent reperfusion contributes to brain injury. Initially, the restriction of blood flow leads to a rapid decrease of oxygen and glucose. Since brain tissue and particularly neurons are almost exclusively dependent on these substrates, they cease to function within minutes. Subsequently, activation of numerous signaling cascades, oxidative stress, mitochondrial dysfunction, and periinfarct depolarization are initiated among other cellular events and cause neuronal necrosis as wells as apoptosis (6). Cells in the ischemic core are irreversibly damaged and quickly undergo necrosis. The surrounding tissue, the so-called penumbra, is still viable, but dysfunctional and extremely vulnerable. After the initial restriction of blood supply, reperfusion and reoxygenation lead to an aggravation of tissue damage particularly in the penumbra area, through the induction of a severe inflammatory, albeit sterile response (7).

\section{Postischemic Inflammation}

Apart from early excitotoxic mechanisms promoting neuronal and glial cell death, the initial lesion enlarges within few hours and days after the ischemic event. This results in deterioration of the neurological deficit and poor functional outcome. A large number of reports support the hypothesis that inflammation is rather a cause than merely a consequence of brain injury. Infarct growth resulting from activation of the immune system by ischemia and subsequent reperfusion is recognized as a major element in all stages of the pathophysiology of ischemic stroke (as illustrated in Figure 1), including long-lasting regenerative processes (3). A reduction of infarct size as well as brain edema and improvement of neurological impairment could by achieved in the middle cerebral artery occlusion (MCAO) animal model by implementing various immunological alterations, such as using immuno-deficient mice, blocking antibodies against pro-inflammatory cytokines, and adhesion-molecules as well as anti-inflammatory treatment (8-13).

In response to the initial brain damage dying cells in the infarct core region release, DAMPs such as adenosin triphosphate (ATP) $(14,15)$ heat shock proteins $(16)$, and high mobility group box 1 protein (HMGB1) (17), which activate pro-inflammatory membrane receptors, such as toll-like receptors (TLRs) and the receptor for advanced glycation end products (RAGE) in the penumbra region. Microglia are among the first immune cells to be activated by DAMPs after stroke (18). The rapid proliferation of resident microglia as well as subsequent infiltration of macrophages can be observed within the first hours following ischemia (19). Both cell types can produce inflammatory cytokines, such as tumor necrosis factor $\alpha$ (TNF $\alpha)$ and Interleukin (IL)-1 $\beta(8,20)$ upon activation of TLRs, RAGE (21), and non-obese diabetic (NOD)like receptor family pyrin domain containing protein (NLRP) 1 and NLPR3. It is well established that activation of TLR2 (22), TLR 4 (21), TLR 8 (23), and NLRP inflammasomes $(24,25)$ have been implicated in the context of postischemic inflammation. In addition, it was also shown that ATP as a DAMP activates the purinergic receptor such as $\mathrm{P} 2 \mathrm{X} 7$ and contributes to postischemic infarct development $(26,27)$.

In addition to the hypoxia and ROS-induced breakdown of the blood-brain barrier (BBB), upregulation of endothelial adhesion molecules and pro-inflammatory cytokines, such as IL-1 $\beta$ and TNF $\alpha$, promote further migration of leukocytes to the site of inflammation through the induction of chemoattractant signals (28). Lymphocytes only constitute a small fraction of infiltrating cells, but still play a prominent role in the evolvement of postischemic inflammation, although the temporal sequence does not correspond to established concepts of adaptive immunity. Mice deficient in lymphocytes have smaller infarcts (29) and specific depletion of the different $\mathrm{T}$ cell subpopulations $\mathrm{T}$ helper cells, cytotoxic T cells, and $\gamma \delta \mathrm{T}$ cells also revealed protective effects $(12,13)$. Whereas CD8 cells are important for perforinmediated cytotoxicity (30), interferon $\gamma$ (IFN $\gamma$ ) secreted by CD4 cells enhances the TNF $\alpha$ production of infiltrating macrophages (8). $\gamma \delta \mathrm{T}$ cells, in turn, produce large amounts of IL-17 in an IL-23-dependent manner (13), which synergistically with TNF $\alpha$ promotes neutrophil recruitment via the chemokine C-X-C motif ligand 1 (CXCL-1) (8). Conversely, administration of anti-IL-17 antibodies diminishes infarct size and improves neurological outcome. Just recently, the role of the inflammatory cytokine IL-21, which is mainly produced by CD4 cells, was also highlighted in the evolvement of postischemic inflammation (31). However, the role of regulatory $\mathrm{T}$ cells (Tregs) is more controversial. It was shown that the depletion of Tregs via the administration of antiCD25 increased lesion size and neurological deficit (32), which led to the hypothesis that Tregs are protective in stroke and that their beneficial function depends on IL-10 (33). Contrary to these findings, Treg depletion through diphteria toxin injection in the DEREG mouse, a model to exclusively deplete Tregs, did not show an effect on lesion size (34). Furthermore, cells of the innate immune system are also involved in the processes of postischemic 


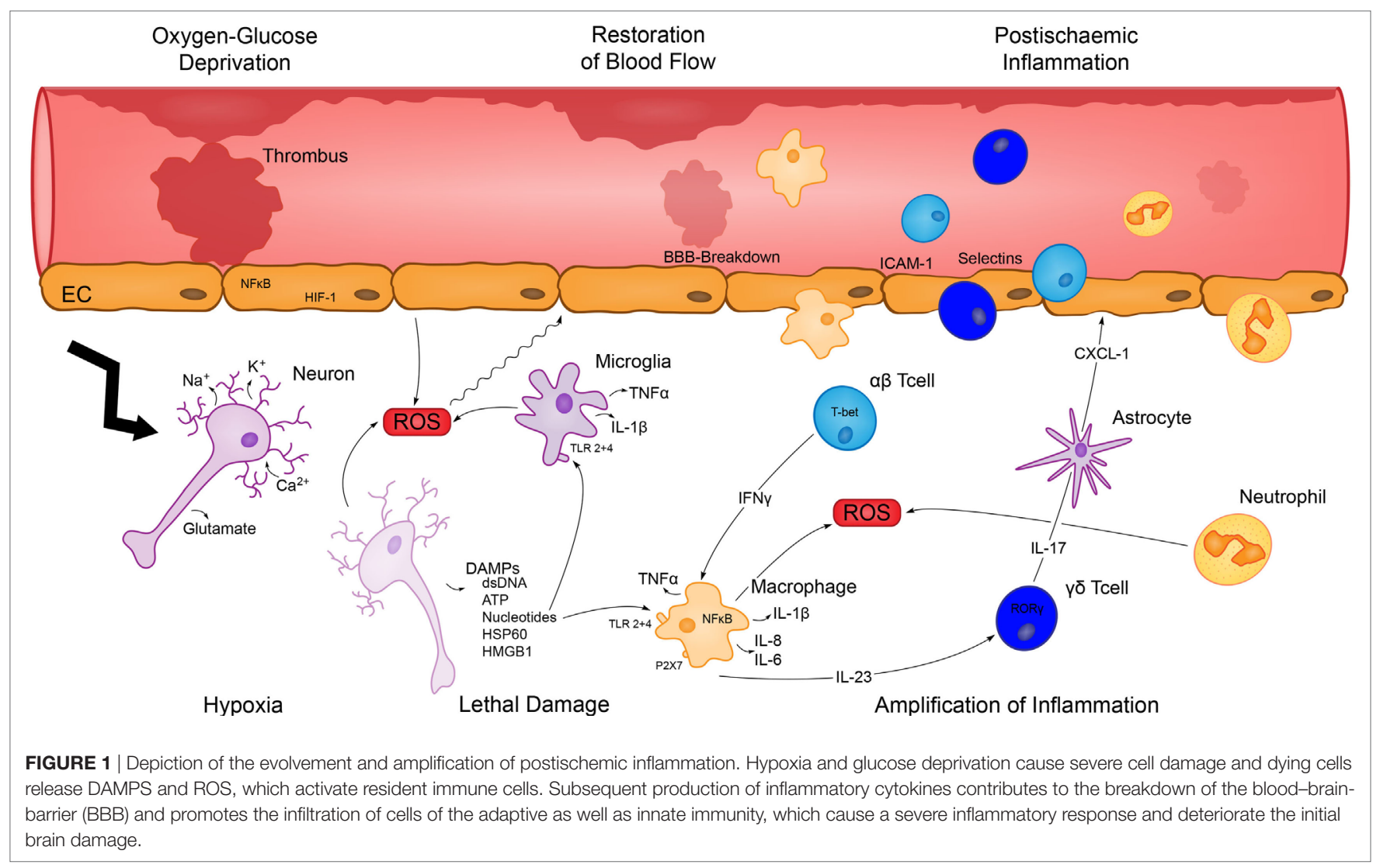

inflammation. The presence of DCs in the ischemic lesion, for instance, is a well-documented feature after stroke, although the functional relevance remains unknown so far (35). Neutrophils account for a substantial number of infiltrating cells (19) and blockade of the IL-17 axis diminishes neutrophil invasion and protects from ischemic stroke (8). Generally, preventing neutrophil migration to the brain has a beneficial effect (36) and neutrophils contribute to further brain damage by producing ROS, proteases, and inflammatory cytokines. Still, they also might have antiinflammatory and neuroprotective functions and a more detailed understanding regarding their role in postischemic inflammation is needed (37). In contrast to the detrimental activation of the immune system in the CNS, a systemic immunosuppression caused by overactivation of the sympathetic nervous system is a common phenomenon following stroke (38). The clinical relevance is underlined by an increased frequency of pulmonary as well as urinary tract infections and can be partially attributed to a long-lasting lymphopenia and impaired cytokine production (39). Furthermore, a loss of innate-like B cells in the spleen, which can rapidly produce immunoglobulin $\mathrm{G}(\operatorname{IgG})$ and $\operatorname{IgM}$ in a $\mathrm{T}$ cell-independent manner and are important in the first-line of antibacterial defense, can be observed (40). Consistent with the loss of B cells murine and human studies have found that ischemic stroke can lead to decreased levels of IgG (41) and IgM (40).

Apart from the deleterious effects, the immunological processes are also a prerequisite for the structural and functional reorganization of the injured brain tissue (3). The inflammatory processes after stroke are self-limiting within the first week after the initial events. Microglia as well as infiltrating macrophages are important for the phagocytosis of dead cells and debris $(18,42)$. They are a source of tropic factors, growth factors $(43)$, and IL-10 (44), thereby facilitating tissue repair. Furthermore, there is evidence that production of growth factors, such as insulin-like growth factor 1 (45) and vascular endothelial growth factor (VEGF) (46), are conducive to neuronal repair. Controversially, some molecules comprise destructive as well as protective capacity. Matrix metallopeptidase 9 (MMP-9), for example, not only exacerbates brain damage in the early phase after stroke (47) but also contributes to neurovascular remodeling and promotes poststroke recovery by converting pro-VEGF into an active form (48). Taken together, activation of the immune system contributes to poststroke inflammation and augments secondary brain damage after stroke. Furthermore, a systemic immunosuppression and an increased susceptibility to infections are observed after stroke. However, it is also important to note that postischemic inflammation may also be involved in regenerative processes. Therefore, it is important to dissect specific detrimental and protective mechanisms when developing new immunomodulatory treatment strategies.

\section{The Postischemic Inflammatory Response in Human Stroke and Translational Approaches}

Most of our current pathophysiological knowledge of the postischemic inflammatory mechanisms derives from murine 
experimental models employing the temporary MCAO mouse model. Despite the difficulty of obtaining postischemic human brain tissue, there is growing evidence of a similar critical inflammatory reaction following stroke in humans, which is based on histopathological postmortem studies and radiological findings. Repetitive magnetic resonance imaging (MRI) showed an enlargement of the ischemic lesion over time by $20 \%$ in selected patients (49) as well as the existence of a penumbra area (50). Migration patterns of infiltrating leukocytes were observed by single photon emission computed tomography and MRI. Neutrophils (51) as well as monocular phagocytes (52) infiltrated the ischemic hemisphere and also microglia were shown to be activated in the human brain following ischemic stroke (53). Brain autopsies validated these findings and showed an infiltration of neutrophils in the ischemic hemisphere within the first $48 \mathrm{~h}$ (54). Furthermore, infiltrating macrophages (52, 55), DCs, and T cells (56) could be found 3 days after stroke onset. Apart from the presence of immune cells, there is also evidence for poststroke inflammation. The pro-inflammatory transcription factor nuclear factor kappa-light-chain-enhancer of activated B cells (NFkb) and chemokines such as CXCL2 were upregulated (57). Furthermore, activated microglia could be detected in the penumbra area (58). Supporting the importance of IL-17, an enormous increase of IL-17 positive cells was found in the ischemic hemisphere (59), mostly in co-localization with infiltrated T cells (8). In addition, IL-17 messenger ribonucleic acid (mRNA) was found to be elevated in leukocytes from stroke patients (60).

In summary, there is substantial preclinical and clinical evidence for a pivotal role of postischemic inflammation in the pathophysiology of ischemic stroke and subsequent induction of further damage to the brain. Considering the limited time window of the available therapies, solely aiming at the restoration of blood supply, there is an urgent need of new treatment strategies. These should not only be applicable in a less restricted period of time but also target the inflammatory and regenerative processes after stroke. Despite the promising results in the mouse model, clinical trials testing neuroprotective and anti-inflammatory agents have largely failed so far $(3,61)$. The underlying cause of the translational roadblock can be attributed to the experimental model. First of all, different genetic backgrounds and significant difference in the composition and the function of the immune system exist between human and mouse (62). Furthermore, there are important varieties in brain morphology, anatomy of cerebral vasculature, and metabolism $(6,63,64)$. Other relevant factors influencing the translation of preclinical studies concern the experimental model regarding the age of the animals and comorbidities, the stroke model in terms of distal versus proximal occlusion as well as transient versus permanent ischemia, outcome measurements, study quality, and selection of patients (65).

A recent example partly elucidating these issues is the investigation of the ability of natalizumab to reduce the detrimental effects of postischemic inflammation. Natalizumab is a monoclonal antibody against CD49d, an $\alpha 4$-integrin, preventing the migration of leukocytes into the brain in a very late antigen4-dependent manner and is approved for the treatment of multiple sclerosis (MS). Anti-CD49d treatment was tested in different animals and distinct models of MCAO with varying periods of ischemia regarding the transient model. One group found a reduction of infarct size in the focal permanent model (30), in general resulting in small cortical infarcts, whereas another group could not reproduce these results (66). Comparable results were published for the transient model, where lesion size increases with the duration of ischemia. Short as well as extended periods of occlusion resulted in protection in some studies $(30,67,68)$ but not exclusively $(30,66)$. In response to those deviating results a preclinical randomized controlled multicentre trial was initiated, which found that anti-CD49d treatment significantly reduced lesion size in the permanent model, but only when data from all centers were analyzed together, whereas there were no differences in the transient model (69). Nevertheless, a clinical study testing a single intravenous injection of natalizumab was conducted from December 2013 to April 2015, showing that natalizumab did not reduce infarct volume, but improved clinical outcome as measured by the modified Rankin Scale (mRS) (70).

Similar controversial is the published data on the immunomodulatory drug fingolimod, which acts as a functional analog of sphingosin-1-phosphate and, therefore, inhibits lymphocyte migration from the lymph nodes to the CNS. Conflicting data are published, mostly describing an impact of fingolimod (13, 71-74) but also challenging the effectiveness (75). Lately, however, two clinical pilot trials succeeded in showing a beneficial effect. Initially, they found in an open-label, evaluator-blinded fashion that fingolimod treatment is safe, attenuated the primary end point infarct growth and improved neurological outcome measured with the National Institutes of Health Stroke Scale and $\mathrm{mRS}$ in a cohort of 22 matched patients, who were not eligible for thrombolysis, given at a mean time of $22 \mathrm{~h}$ after symptom onset (76). The follow-up randomized, open-label, evaluatorblind multicenter trial investigated the effect of early fingolimod treatment in addition to thrombolysis (77). 47 patients, with 22 receiving fingolimod and $\mathrm{rt}-\mathrm{PA}$, were enrolled in the study and significant beneficial effects for the primary endpoints changes in lesion volume and extent of clinical improvement from baseline to day 1 as well as for the secondary endpoints extent of lesion volume growth and clinical improvement from day 1 to day 7 were observed. However, an unusual high rate of reperfusion of more than $60 \%$ was described in the second study and it needs to be considered that these studies have a proof of principle character and further multicenter, randomized, double-blind, and placebocontrolled trials will be necessary to confirm these results.

\section{Fc $\gamma$ Rs AND INTRAVENOUS IMMUNOGLOBULIN (IVIg)}

Among many other immunomodulatory drugs, IVIg have been shown to be beneficial in experimental stroke in recent studies. IVIg contain polyclonal IgG and many different mechanisms of action have been proposed, of which the Fc fragment-dependent pathways seem to be of major significance. IVIg are established as a first-line therapy in different kinds of autoimmune disease. Although the mechanisms in stroke are not well understood so far, they possess promising therapeutic potential through neuroprotective and immunomodulatory pathways. 


\section{Fc $\gamma$ Receptors}

Fc receptors are found on the surface of a variety of cells and specifically bind to the Fc region of immunoglobulins (Igs). Four different subclasses of Fc receptors for IgG (Fc $\gamma$ Rs) have been identified in mice, including the activating receptors Fc $\gamma \mathrm{RI}$, Fc $\gamma$ RIII, and Fc $\gamma$ RIV as well as the inhibitory receptor Fc $\gamma$ RIIB (78). All Fc $\gamma$ Rs belong to the Ig superfamily. The activating receptors share a common $\gamma$-chain that comprises an immunoreceptor tyrosin-based activating motif (ITAM) (79) and express an individual ligand-binding $\alpha$-chain, whereas the inhibitory Fc $\gamma$ RIIB is a single chain receptor containing an immunoreceptor tyrosinbased inhibitory motif (as illustrated in Figure 2).

Besides microglial, endothelial, and mesangial cells as well as osteoclasts (78), FcyRs are particularly expressed by leukocytes. The majority of immune cells co-express activating and inhibitory Fc $\gamma$ Rs and the ratio of these receptors expressed by individual cells set a threshold for cell activation. Apart from distinct Fc $\gamma$ Rs, four different subclasses of IgG, in mice IgG1, IgG2a, IgG2b, and IgG3, with varying affinities toward the Fc $\gamma$ Rs are known. Fc $\gamma$ RI shows high affinity and specificity for the different IgG isotypes, in contrast to FcyRIIB and FcyRIII that have lower binding capacities but recognize a broader spectrum (80). Fc $\gamma$ RIV, in turn, seems to be the most important receptor for effector function of IgG2a and IgG2b (81). Moreover, it needs to be considered that the low-affinity receptors Fc $\gamma$ RIIB, Fc $\gamma$ RIII, and Fc $\gamma$ RIV can only interact with multimeric IgG, which is present in immune complexes (ICs). This prevents unspecific binding, whereas Fc $\gamma$ RI is saturated with monomeric serum IgG, but also requires ICs for activation (82). These kinetics suggest that the low-affinity receptors can regulate immunity more effective since the high-affinity binding to monomeric IgG of Fc $\gamma$ RI hampers interaction with ICs (78). Apart from FcyRs IgG also binds to the neonatal Fc receptor (FcRn), which is expressed by vascular endothelium. FcRn prevents catabolism of IgG and is important for IgG half-life (83).

Triggered by the crosslinking of ICs with the $\alpha$-chain of the activating FcyRs, the ITAM becomes phosphorylated, leading to the activation of members of the family of spleen tyrosin kinases (SYK) $(78,84)$. Subsequently, SYK-dependent phosphoinositides increase the activity of phospholipase $\mathrm{C} \gamma$ (PLC $\gamma$ ) and Bruton's tyrosine kinase (BTK) $(78,84)$ leading to an increase of intracellular calcium levels. Upon activation of FcyRIIB, in turn, the SH2-containing inositol polyphosphate 5-phosphatase (SHIP) hydrolyzes phosphoinositides (85). This events lead to a reduction of the activity of kinases, such as PLC $\gamma$ and BTK, and, therefore, diminish the increase of intracellular calcium $(78,84)$. Hereby, activating as wells as inhibitory receptors affect

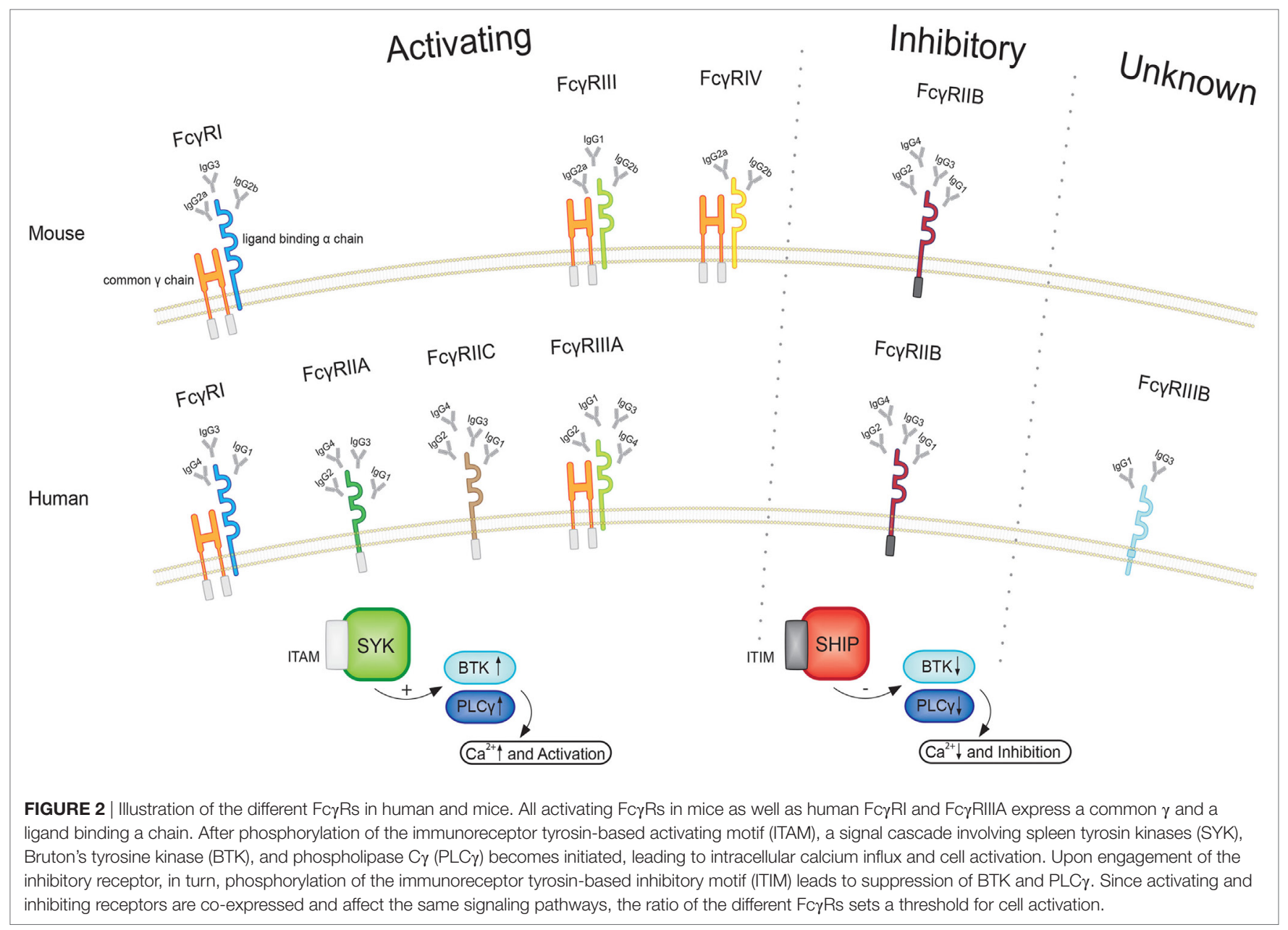


the same signaling pathway and FcyRIIB exhibits important negative regulatory function in this manner. The loss or impairment of this inhibitory receptor can lead to autoimmunity as well as a prolonged immune response (86). The balance of activating and inhibitory receptors can be altered by the surrounding cytokine environment. The diverse role of $\mathrm{Fc}$ receptors in autoimmunity is elucidated by the fact that $\mathrm{Fc}$ receptor common $\gamma$-chain $(\mathrm{FcR} \gamma)$ knockout mice are resistant to the induction of autoimmune disease or show a milder course of disease, whereas FcyRIIB knockout mice often show worse outcome compared to wild-type mice (87-89). Mechanistically, it could be shown in nephrotoxic nephritis that DCs from FcyRIIB knockout animals show a more pronounced expression profile of cytokines associated with $\mathrm{T}$ cell activation that is absent in FcR $\gamma$-deficient mice (90). Furthermore, autoimmune-prone mouse-strains show a reduced expression of FcyRIIB, which is due to a promoter polymorphism in the Fcgr2 region (91). However, it needs to be considered that the $\mathrm{FcR} \gamma$-chain is not only expressed by activating Fc $\gamma$ Rs but is also associated with a variety of other receptors, such as the T cell receptor (TCR)-CD3 (cluster of differentiation) complex, Fc $\alpha$ R, FceR, Nkp46, and IL3 $(79,92)$, when using the FcR $\gamma$ knockout animals.

Human Fc receptors have a similar nomenclature and signaling pathways, but possess different expression patterns and binding affinities. So far, six different Fc $\gamma$ Rs have been identified. The high-affinity receptor FcyRI and the low-affinity receptors Fc $\gamma$ RIIA, Fc $\gamma$ RIIC, and Fc $\gamma$ RIIIA are activating receptors, whereas Fc $\gamma$ RIIB is inhibitory and the function of Fc $\gamma$ RIIIB is yet unknown (93). The different IgG isotypes in humans are named IgG1, IgG2, IgG3, and IgG4, which bind to the different Fc $\gamma$ Rs in a concentration-dependent manner (94). Functionally, in humans IgG1 and IgG3 are the most pro-inflammatory IgG subclasses, whereas in mice IgG2a and IgG2b show a high inflammatory activity (78).

Taken together, humans and mice possess a similar repertoire of different Fc $\gamma$ Rs regarding their function and share common pathways. However, an important characteristic is the high rate of Fc $\gamma \mathrm{R}$ polymorphisms in humans (95), which affect binding affinities for IgG (94) and are associated with different kinds of autoimmune disease as well as immunological function (96).

\section{Immunomodulatory Effects of IVIg in Autoimmune Disease}

Intravenous immunoglobulins are therapeutic preparations of polyclonal IgG, which are extracted from the plasma of thousands of donors. The different IgG subclasses are similarly distributed in IVIg preparations like in the blood of healthy individuals. Different mechanisms of action for IVIg in diseases models have been proposed. The Fc-mediated effects are most likely of major significance (97), which is supported by the fact that infusion of IgG preparations only containing the Fc fragment can protect mice as wells as humans from disease $(98,99)$. First of all IVIg can compete for activating Fc $\gamma$ Rs and, therefore, limit the access of activating ICs (100). In a similar manner, IVIg can inhibit complement deposition (101). The inhibitory receptor Fc $\gamma$ RIIB seems to be essential for the protective effects, since protection by
IVIg is lost in FcyRIIB-deficient mice and Fc $\gamma$ RIIB is upregulated following IVIg treatment $(88,99)$. Mechanistically, Fc $\gamma$ RIB signaling can suppress B cell-mediated T cell-dependent immune responses (102). Specific intracellular adhesion molecule grabbing none-integrin receptor 1 (SIGN-R1) and its human homolog dendritic cell-specific intracellular adhesion molecule-3 grabbing non-integrin, which is among others expressed by macrophages (103), have also been proposed to be important in IVIg function mediated by Fc $\gamma$ RIIB. These two receptors can directly recognize specific sialic acid rich isoforms of IgG, which leads to an up to tenfold increase of effectiveness of IVIg (104) and induces a noninflammatory phenotype in a specialized subset of macrophages. Conversely, macrophage colony-stimulating factor 1 (M-CSF-1)deficient mice also loose IVIg protection, which might be due to a lack of M-CSF-1-dependent regulatory SIGN-R1 expressing macrophages (105). Furthermore, inhibition of BTK, a kinase downstream of FcyRs, whose activity is reduced upon Fc $\gamma$ RIIB activation, leads to reduced mature IL- $1 \beta$ in the context of inflammation (25), as well as preventing IL-1 $\beta$, IL-17, IFN $\gamma$, and TNF $\alpha$ production upon FcyR stimulation (106).

Another proposed functional pathway is the ability of IVIg to neutralize anti-ideotypic antibodies in a $\mathrm{F}(\mathrm{ab})^{2}$ fragmentdependent manner and, therefore, protect from disease (107). Other $\mathrm{F}(\mathrm{ab})^{2}$ fragment-dependent mechanisms include blockade of specific receptors, such as the Fas receptor via anti-Fas antibodies (108), the binding of cytokines such as IL-5 as wells as granulocyte macrophage colony-stimulating factor (109) and the inhibition of TCR-mediated T cell proliferation (110). In addition, IVIg do not only hemper $\mathrm{T}$ cell proliferation but can also influence the differentiation of T helper cells into Th17 cells via interference with the retinoic acid-related orphan receptor $\mathrm{C}$ (111) and can induce a shift toward a Th2 phenotype in childhood ITP and women with recurrent spontaneous abortion $(112,113)$. Furthermore, there is evidence that IVIgs increase the expression of IL-10 as wells as TGF- $\beta$ in T regulatory cells (114) via specific epitopes in the Fc region of IgG (115). Interestingly, IVIg were also able to bind to peripheral blood T cells, which do not express Fc $\gamma$ Rs, through yet unknown receptors (116) and can reduce the production of inflammatory cytokines, such as IL-2, IL-3, IL-4, IL-5, IFN $\gamma$, and TNF in in vitro setting (117).

Taken together IVIg can act through a variety of different pathways. Apart from $\mathrm{Fc}$ and $\mathrm{F}(\mathrm{ab})^{2}$ fragment-dependent effects, IVIgs can either indirectly or even directly address cells that do not express FcyRs. The individual roles and mechanisms need to be explored individually in the different autoimmune diseases, also considering that there are probably joint effects.

\section{Fc $\gamma$ Rs and IVIg in Neurological Disease Expression of FcyRs in the CNS}

There is growing evidence for a pivotal role of Fc receptors in the pathophysiology of disorders of the CNS, but the existence of the distinct Fc $\gamma$ Rs within the cell types of the CNS are still not fully explored. Especially the functionality and expression profile of FcyRs in neurons remains controversial. Nevertheless, mRNA of all Fc $\gamma$ Rs has been found in primary mouse superior cervical ganglion cultures and an intracellular calcium increase upon stimulation with IgG could be detected (118). Considering that 
Fc $\gamma \mathrm{R}$ signaling in immune cells causes an intracellular calcium increase via SYK and subsequent activation of BTK and PLC $\gamma$, it is conceivable that the same pathway is enabled in neurons. Fc $\gamma$ RI has also been found on dorsal root ganglions, similarly causing intracellular calcium increase (119), whereas FcyRIII was expressed by primary neuronal cell cultures (120). Fc $\gamma$ RIV could be detected in the hippocampal area and temporal cortex in mice brain (121). Likewise, the inhibitory receptor FcyRIIB is expressed by neurons (122) and has an important function in the cerebellum during development (123). Little is known about the regulation of these receptors in neurons, but elevated mRNA levels of all Fc $\gamma$ Rs could be found in response to an increase of intracerebral IgG in a model of experimental hypercholesterolemia (121).

Microglia express all FcyRs (124) and their expression levels are upregulated in response to inflammation and cytokines, such as IFN $\gamma$, TNF, and IL-1 $\beta$ (125-128). Upon stimulation with monoclonal antibodies against the FcR $\gamma$-chains I, IIA, III, but not IIB human microglia can produce inflammatory cytokines such as macrophage inflammatory protein $1 \alpha$ (129). Furthermore, it could be shown that the expression of Fc $\gamma$ RIV increases with age and upon lipopolysaccharide stimulation (130). An upregulation of all Fc $\gamma$ Rs in models of chronic neurodegeneration in response to inflammatory stimuli was also observed (131), whereas Fc $\gamma$ RI and Fc $\gamma$ RIIb were downregulated on microglia of $\mathrm{AD}$ patients after immunotherapy $(132,133)$. Apart from microglia, astrocytes and oligodendrocytes are also known to contribute to postischemic inflammation, but only limited data on the expression of FcRs are available in these cell types. Astrocytes have been reported to express Fc $\gamma$ RI and Fc $\gamma$ RIIB (134), whereas oligodendrocyte precursor cells (OPCs) express $\mathrm{FcR} \gamma$ as well as the alpha chain of FcyRI and FcyRIII (134). Stimulation with anti-FcR $\gamma$ as well as IgG induces differentiation into myelinating oligodendrocytes, suggesting that Fc $\gamma$ Rs are expressed on cells of the oligodendrocytes lineage and are important for myelination. Conversely, the FcR $\gamma$ mice show hypomyelination (135).

In summary, there is much evidence that all Fc $\gamma$ Rs are expressed in neurons, microglial as well as other glial cells of the CNS. Particularly the inhibitory receptor FcyRIIB could be found on all cell types. Their existence seems to be not exclusively important in immunological processes but also in the context of development of the CNS.

\section{Immunomodulatory Effects of IVIg in Neurological Disease}

Intravenous immunoglobulins are established as a first-line therapy in a variety of neurological disease. They are used in the treatment of CIDP, Guillain-Barré syndrome (GBS), myasthenia gravis, and inflammatory myopathies as well as in autoimmune encephalitis and neuromyelitis optica $(136,137)$. CIDP, for example, is a heterogeneous autoimmune-mediated inflammatory demyelinating disease of peripheral nerves and several clinical trials showed that IVIg are beneficial (138). The pathophysiology of disease remains unknown; but in a subset of patients, it appears to be mediated by IgG-autoantibodies against myelin. IgG isolated from this group of patients was able to induce disease in rats (91), suggesting that IgG can play an important role in the development of CIDP. Furthermore, the NODmouse strain, which has a promoter polymorphism in the Fcgr2 region (139), can develop spontaneous autoimmune peripheral polyneuropathy under certain circumstances $(140,141)$. Conversely, Fc $\gamma$ RIIB expression is impaired in B cells of patients with CIDP but is upregulated following IVIg treatment (142). Likewise, for GBS, another disease of the peripheral nervous system (PNS), IVIg represent an established therapeutic regime. In approximately $50 \%$ of patients with the GBS, autoantibodies against gangliosides can be found (143). One of the proposed mechanisms of IVIg action in GBS as wells as CIDP is the presence of anti-ideotypic antibodies that are able to bind and neutralize pathogenic autoantibodies (144). Another exemplary IgG-mediated neurological disorder is myasthenia gravis, in which autoantibodies against the acetylcholine receptor are produced in a T helper cell-dependent manner. Mechanistically, IVIg protection in myasthenia gravis is also most likely promoted by anti-ideotypic antibodies.

Apart from the efficacy to treat PNS affecting diseases, data for IVIg on diseases of the CNS is more controversial. Although beneficial effects and potential therapeutic pathways have been observed in the mouse model of MS (145) and AD, for example, translation into the human system remains difficult so far. A major limiting factor in the context of diseases of the CNS is the $\mathrm{BBB}$, which controls access of IVIg to the brain. In the healthy brain, IgG is present in small amounts and is able to cross the $\mathrm{BBB}$ in a controlled manner through yet unknown mechanism. The clearance from the CNS is mediated by the FcRn (146), which is expressed by brain endothelial cells (147, 148). In the context of inflammation, when the BBB is disrupted, IVIg are able to enter the brain in a less restricted manner. Accordingly, following administration of IVIg in a model of experimental stroke, increased intracerebral IgG was observed in the ischemic brain $(147,148)$. IVIg is also able to cross the intact $\mathrm{BBB}$ in a saturation-dependent process and were found to co-localize with neurons as well as endothelial cells (149). Interestingly, administration of IVIg reduced the amount of endogenous IgG in this model, suggesting a competition for brain access. A positive impact of IVIg on the integrity of the $\mathrm{BBB}$ has also been reported, since IVIg treatment was able to prevent BBB-breakdown in sepsis (150).

For MS, which is suggested to be primarily a T cell-mediated disease, there is experimental evidence from the experimental autoimmune encephalitis (EAE) model that treatment with IVIg is beneficial. It could be shown that IVIg decreased the production of inflammatory cytokines such as IFN $\gamma$ and TNF $(144,151)$ on one side and led to an expansion of peripheral $\mathrm{T}$ regulatory cells and subsequent suppression of conventional $\mathrm{T}$ helper cells in an Fc-fragment independent manner on the other side (152). Apart from the impact on the cells of the adaptive immunity, there is also evidence for a direct involvement of Fc $\gamma$ Rs. It could be shown that FcR $\gamma$-deficient mice develop milder EAE (89), although this effect was attributed to $\gamma \delta$ T cells that use this chain in other receptors than the Fc $\gamma$ R. In addition, the FcR $\gamma$ can be detected on OPCs in remyelinating plaques in MS as well as on microglia in inactive plaques (153). Despite the beneficial action in the experimental setting, the effect of treatment in humans is 
controversial. Some small studies were able to show protection, whereas a large multicentre, randomized, double-blind, placebocontrolled trial failed to reproduce the previous results (154).

\section{IVIg IN ACUTE BRAIN INJURY}

\section{Current Knowledge of Fc Receptors and IVIg in Stroke}

Only little is known about the role of FcyRs in the context of postischemic inflammation, but various experimental studies emphasize a promising therapeutic effect of IVIgs in the in vivo stroke model as well as in in vitro settings by reducing infarct size and improving neurological outcome. The direct mechanisms remain unknown so far. First of all, it could be shown in the MCAO model that the common $\gamma$-chain knockout, which lacks all activating Fc $\gamma$ Rs, is protected from stroke (155). Compared to WT mice, the common $\gamma$-chain-deficient mice showed significant reduction of infarct volume at $24,72 \mathrm{~h}$, and 14 days after stroke as well as an improved neurological outcome after being subjected to $60 \mathrm{~min}$ of transient focal ischemia. Mechanistically, it was assumed that Fc $\gamma$ Rs are important for the activation of microglia and induction of the inducible nitric oxide synthase (iNOS). Hence, microglia of the common $\gamma$-chain $\mathrm{KO}$ mice expressed fewer ionized calcium-binding adapter molecule 1, a protein that is upregulated in microglia upon activation, as well as less iNOS in immunohistochemistry and on protein level.

In addition to the effects mediated by inhibition of the activating Fc $\gamma$ Rs, it was recently shown that IVIg treatment likewise protects the brain from ischemia-induced reperfusion injury and the subsequent inflammatory response. Administration of IVIg, $3 \mathrm{~h}$ post reperfusion significantly reduced the amount of infiltrating leukocytes $24 \mathrm{~h}$ after MCAO, which were identified as CD45 high cells in flow cytometry (156). In line with recent preclinical studies showing a beneficial effect of the $\alpha 4$-integrin-inhibitor natalizumab in experimental stroke, the reduction of infiltrating leukocytes by IVIg could be mediated in an $\alpha 4$-integrin-inhibitordependent manner as it has been shown in the EAE model (157). Of note, this study concluded that IVIg treatment is even detrimental in stroke, since they found more leukocytes occupying pial vessels, which is thought to be due to platelet-mediated pro-adhesive effects. Still, it needs to be considered that they did not examine the actual number of infiltrating cells.

Furthermore, IVIg treatment of primary neuronal cultures subjected to oxygen and glucose deprivation, an in vitro model of ischemic stroke, inhibited upregulation of TLR2, TLR4, and TLR8 (158). These findings could also be reproduced in vivo where IVIg administration after transient MCAO significantly reduced ischemia-induced upregulation of TLR2, TLR4, and TLR8. The authors also observed an IVIg-dependent suppression of HMGB1-mediated TLR activation, which is released by dying cells as a danger signal in the context of ischemic stroke. In addition, it was found that IVIg attenuated the ischemia-induced increase of complement factor C3b, which is known to contribute to ischemic injury (159) and among others upregulates the intracellular adhesion molecule 1 (ICAM-1) in vivo and in vitro. In line with these findings, IVIg also specifically affect endothelial cells and diminish the upregulation of VCAM-1 and ICAM-1 in in vitro settings (160).

Another immunomodulatory IVIg mechanism includes the suppression of the NLPR1 and NLPR3 inflammasome-mediated neuronal cell death $(24,25)$. Treatment of primary neuronal cultures with IVIg subjected to simulated ischemia as well as mice subjected to MCAO, reduced levels of inflammasome components such as NLRP1, NLRP3, and apoptosis-associated specklike protein containing a caspase recruitment domain (ACS). This, in turn, led to a reduction of caspase- 1 and mature IL-1 $\beta$ as well as IL-18. Moreover, it was shown that selective inhibition of BTK with ibrutinib, whose activity is reduced after engagement of the inhibitory receptor Fc $\gamma$ RIIB, diminishes ischemic injury by decreasing inflammasome NLPR3 activity and, therefore, conversion of pro-IL-1 $\beta$ (25). Conversely, the inhibition of SYK, a kinase upstream of BTK was also able to decrease lesion size in the MCAO model (161). Interestingly, IVIg protection in other autoimmune disease is lost in M-CSF-1-deficient (op/op) mice. Apart from an enormous reduction of microglia proliferation, these M-CSF-1-deficient mice show an enhanced sensitivity to ischemia-induced neuronal injury and cell death (162). M-CSF-1 overexpression, in turn, leads to microglia proliferation, which does not show a difference in phenotype regarding the M1/M2 model, but shows altered immune responses (163). Importantly, M-CSF-1 treatment of mice subjected to MCAO decreases infarct size (162) and the presence of M-CSF-1-dependent macrophages correlates with an increased expression of Fc $\gamma$ RIIB (164).

Apart from ameliorating the inflammatory response after stroke the protective capacity of IVIg includes the induction of neuroprotective pathways. For instance, neuronal structure was more intact and had less ischemia-associated alterations on a histopathological level in IVIg-treated rats (165). IVIg treatment of primary neuronal cultures subjected to simulated ischemia for $12 \mathrm{~h}$ significantly reduced protein levels of factors involved in neuronal cell death like the phospho-SAPK c-Jun $\mathrm{NH}^{2}$ terminal kinase (p-JNK) and phospho-p65 NFkB and inhibited the loss of the neuronal marker microtubulin associated protein 2 (MAP2) (147, 158). These findings could be confirmed by immunoblots and immunohistochemistry, respectively, in vivo in the transient MCAO model. Furthermore, IVIg could prevent simulated ischemia-induced endothelial disintegration in a brain endothelial cell line and increased the protective protein B-cell lymphoma 2 produced by these endothelial cells as well as by neurons (156). In line with these findings it could be shown that ischemia-induced decrease and reduced phosphorylation of low-density lipoprotein receptor-related protein 1, which is abundantly expressed by neurons, can be inhibited by IVIgs and, subsequently, prevents activation of cell death signaling proteins as NFkB and p-JNK (166).

Apart from the already described pathways, there are multiple other conceivable mechanism how IVIg facilitate protection in the context of ischemic stroke (Figure 3). They could inhibit complement deposition and induce a regulatory phenotype in macrophages in an Fc-fragment manner, as well as targeting the inhibitory receptor FcyRIIB, subsequently supressing T cellmediated immune responses. Similary, the production of inflammatory cytokines, such as IL- $1 \beta$ and TNF $\alpha$, could be diminished 


\begin{tabular}{|c|c|c|}
\hline & FcyR Expression & Proposed IVIg Mechanism \\
\hline Neurons & 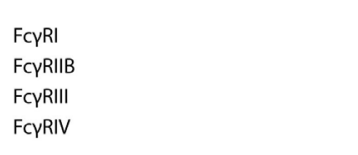 & $\begin{array}{l}\downarrow \text { Apoptosis ( } \mathrm{p}-J \mathrm{NK}, \mathrm{NFKB}, \mathrm{MAP} 2, \mathrm{LRP} 1 \text { ) } \\
\downarrow \quad \mathrm{TLR} 2,4 \text { and } 8 \text { expression } \\
\downarrow \text { Inflammasome activity }\end{array}$ \\
\hline Microglia & 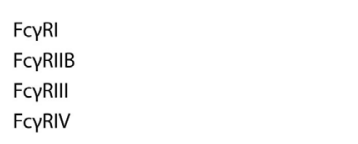 & $\begin{array}{ll}\downarrow & \text { Activation } \\
\downarrow & \text { Proinflammatory cytokines (IL-1 } \beta, \mathrm{IL}-6, \mathrm{TNF} a) \\
\downarrow & \text { iNOS expression and NO production }\end{array}$ \\
\hline Endothelial cells & $\begin{array}{l}\text { FcyRIIB } \\
\text { FcyRIII }\end{array}$ & $\begin{array}{ll}\uparrow & \text { Blood-Brain-Barrier Stabilisation } \\
\downarrow & \text { Adhesion molecules (ICAM-1 and VCAM) } \\
\uparrow & \text { Bcl-2 }\end{array}$ \\
\hline Infiltrating cells & $\begin{array}{l}\text { Monocytes: FcyRI, IIB, III, IV } \\
\text { Neutrophils: FcyRIIIB, III, IV } \\
\text { Innate Lymphocytes: FcyRIII } \\
\text { Adaptive Lymphocytes: FcyRIIB (Bcells) }\end{array}$ & $\begin{array}{ll}\downarrow & \text { Infiltration of peripheral immune cells } \\
\downarrow & \text { Proinflammatory cytokines (IL-1 } \beta, \mathrm{IL}-6, \mathrm{TNFa}) \\
\downarrow & \text { Proliferation of conventional Thelper cells via indirect mechanisms } \\
\uparrow & \text { Expansion of T regulatory cells via yet unknown receptors }\end{array}$ \\
\hline
\end{tabular}

FIGURE 3 | Keyplayers in acute brain injury and their expression of FcyRs as well as their proposed role in intravenous immunoglobulin (IVIg)-mediated protective effects.

in Fc $\gamma$ Rs expressing cells. In addition, the $\mathrm{F}(\mathrm{ab})^{2}$ fragment could block receptors such as Fas (167) or inhibit TCR-mediated T cell proliferation. Also indirect effect such as increased IL-10 and TGF- $\beta$ expression as well as a reduced production of inflammatory cytokine by $\mathrm{T}$ cells need to be considered. Ultimately, it remains unsolved wheter IVIg primarily operate via the Fc or $\mathrm{F}(\mathrm{ab})^{2}$ fragment, or if indirect mechanisms such as T cell inhibition predominate.

\section{IVIg in Other Models of Acute CNS- and Ischemia-Reperfusion Injury}

Besides experimental evidence for positive IVIg effects in postischemic inflammation, there are other models of acute CNS injury in which IVIg have been shown to be beneficial. Similar to inflammatory processes following ischemic stroke, neuroinflammation exacerbates the tissue damage in acute spinal cord trauma (168). Accordingly, several hallmarks of sterile inflammation have been observed following trauma: (i) microglia activation; (ii) upregulation of proinflammatory cytokines, including IL-1 $\beta$, TNF $\alpha$, and IL- 6 as well as ROS and MMP-9; and (iii) infiltration of neutrophils, monocytes, and lymphocytes. The importance of the local inflammation is underlined by studies showing that immunosuppressive treatment approaches with steroids have favorable effect on functional outcome. Nevertheless, the disadvantage of unspecific immunosuppressive agents is demonstrated by studies showing an increased risk of infection following steroid treatment in models of traumatic spinal cord injury. Consequently, more specific immunomodulatory treatment strategies are needed. The feasibility of immunmodulatory treatments in acute spinal cord injury was recently demonstrated by Gok et al. (169), describing that the treatment with IgG had significant beneficial effects on motor function in a rat model. Furthermore, electron microscopy revealed a significant decrease of intraneuronal vacuoles, as an indicator for more preserved neuronal ultrastructure. Another study on IgG in acute spinal cord injury also showed reduced scar formation and tissue preservation on a histopathological level (170). In addition, the authors detected a reduction in proinflammatory cytokines, such as TNF $\alpha$, IL-1 $\beta$, and IL- 6 as well as MMP9, and showed that the IgG is able to enter the injured spinal cord while it mainly co-localized to astrocytes. Furthermore, protective IVIg effects were associated with reduced numbers of infiltrating neutrophils as wells as a diminished MPO activity. Overall, the reduction of inflammation showed improved functional recovery assessed by neurobehavioral test as well as significantly enhanced conduction velocity in electrophysiological measurements.

Sterile inflammation is also a well-known feature after traumatic brain injury (171). As a consequence of the initial trauma a tremendous release of DAMPs can be observed, which induced production of proinflammatory cytokines and infiltration of various immune cells. Incidentally, it was found that IgG significantly improved motor test scores compared to saline and reduced MPO activity, as it was used as an additional vehicle control in a study investigating the effect of ICAM-1 blockage in traumatic brain injury (172). Furthermore, it could be shown that IVIg treatment stabilized the BBB and reduced edema formation (173). These effects were accompanied by reduced amounts of IL-6 upon IVIg administration as well as less infiltrating macrophages and increased neuronal density. Moreover, endothelial protection by IVIg was detected in a model of subarachnoidal hemorrhage (174). 
Intravenous immunoglobulin have also been investigated in other models of ischemia-reperfusion injury and a protective effect on the evolving inflammatory cascades has been observed. In mesenteric ischemia, a condition that can be associated with hypovolaemic shock, sepsis, and cardiac arrest (175), pretreatment with IVIg reduced complement-mediated tissue damage (176). IVIg also significantly reduced mucosal injury on a histopathological level and diminished C3 deposition in the intestinal mucosa. Interestingly, the number of infiltrating leukocytes was not altered by IVIg administration. Similarly, in a model of liver ischemia, sinusoidal congestion and cytoplasmatic vacuolation were diminished in IVIg-treated mice (177). These effects were associated with a reduced mortality in the IVIg-treated group. Taken together, there are multiple pieces of evidence from experimental studies that IVIg have significant protective effects on acute injuries of the CNS and other organs, in which sterile inflammation is part of the pathology.

\section{Implications for the Clinical Use of IVIg in Acute Brain Injury}

Reflecting the available preclinical data on IVIg in acute brain injury, it seems promising to also use IVIg in a clinical setting. However, possible rheologic disadvantages need to be considered. It does not appear intuitively that an agent, which could possibly deteriorate perfusion due to the high viscosity, is suitable to treat diseases with reduced blood flow and impairment of microcirculation. Indeed, IVIg-related thrombosis has been described in the literature sporadically (178). Nevertheless, the positive impact of IVIg seems to predominate these negative effects. Overall, these drawbacks might be overcome in future studies, if specific therapeutic effects can be attributed to single IVIg fractions, thereby allowing to reduce the necessary dosage.

Considering that peripheral immunosuppression and an increased risk of urinary tract as well as upper airway infections is a common epiphenomenon after stroke IVIg treatment shows another promising potential. Apart from reducing the inflammatory reactions after stroke, IVIg administration could also compensate for the transient decrease of IgG after stroke (41) and possibly reduce the risk of infections that deteriorates the outcome of stroke patients. In line with this assumption, it could be shown that IVIg can even enhance microbial-specific immune responses in preterm infants (179) and do not increase mortality in sepsis (180). One clinical trial exploring the effect

\section{REFERENCES}

1. Chen GY, Nuñez G. Sterile inflammation: sensing and reacting to damage. Nat Rev Immunol (2010) 10(12):826-37. doi:10.1038/nri2873

2. Chamorro Á, Dirnagl U, Urra X, Planas AM. Neuroprotection in acute stroke: targeting excitotoxicity, oxidative and nitrosative stress, and inflammation. Lancet Neurol (2016) 15(8):869-81. doi:10.1016/S1474-4422(16)00114-9

3. Iadecola C, Anrather J. The immunology of stroke: from mechanisms to translation. Nat Med (2011) 17(7):796-808. doi:10.1038/nm.2399

4. McGeer PL, McGeer EG. The inflammatory response system of brain: implications for therapy of alzheimer and other neurodegenerative diseases. Brain Res Brain Res Rev (1995) 21(2):195-218. doi:10.1016/0165-0173(95)00011-9

5. Feigin VVL, Forouzanfar MH, Krishnamurthi R, Mensah GA, Connor M, Bennett DA, et al. Global and regional burden of stroke during 1990-2010: of IVIg in human stroke was already initiated (clinicaltrials. gov NCT01628055), but had to be stopped due to difficulties in patient recruitment.

\section{CONCLUSION}

Taken together, there is growing evidence that the rapid activation of the immune system in response to acute sterile tissue damage can be detrimental for the affected organ. Particularly, postischemic inflammation following stroke has been investigated extensively and multiple preclinical studies emphasize beneficial IVIg effects in models of acute brain injury, i.e., ischemic stroke, spinalcord, and traumatic brain injury. The already established use of IVIg in various neurological diseases is a major advantage. Furthermore, available data suggest that IVIg are specifically modulating harmful inflammatory processes, without relevant immunosuppressive side effects.

In general, IVIg exert protective effects in autoimmune disease via multiple mechanisms. Similarly, in acute brain injury, it is most likely that IVIg protection is mediated by the interaction with different targets concomitantly, which merge to a mutual effect. In this context, immunomodulatory pathways are among the most promising candidates. IVIg can target microglia as resident immune cells of the CNS as well as immune cells from the systemic immune compartment and endothelial cells. Furthermore, it is important to mention that IVIg can stabilize the BBB and even facilitate direct neuroprotection. Eventually, it currently remains concealed if IVIg effects are $\mathrm{Fc}$ or $\mathrm{F}(\mathrm{ab})^{2}$ fragment dependent and if IVIg can modulate cells indirectly, which are not expressing Fc receptors in this context. Although the currently existing data are promising, further research is needed to gain more insight into protective IVIg-dependent mechanisms and to explore the therapeutic potential of IVIg in acute brain injury.

\section{AUTHOR CONTRIBUTIONS}

VT, TM, TA, and MG contributed to the concept design, writing, and final approval of the manuscript; VT drew the figures.

\section{FUNDING}

This study was funded by Hermann und Lilly Schilling-Stiftung für Medizinische Forschung. findings from the global burden of disease study 2010. Lancet (2014) 383(9913):245-55. doi:10.1016/S0140-6736(13)61953-4

6. Dirnagl U, Iadecola C, Moskowitz MA. Pathobiology of ischaemic stroke: an integrated view. Trends Neurosci (1999) 22(9):391-7. doi:10.1016/ S0166-2236(99)01401-0

7. Macrez R, Ali C, Toutirais O, Le Mauff B, Defer G, Dirnagl U, et al. Stroke and the immune system: from pathophysiology to new therapeutic strategies. Lancet Neurol (2011) 10(5):471-80. doi:10.1016/S1474-4422(11)70066-7

8. Gelderblom M, Weymar A, Bernreuther C, Velden J, Arunachalam P, Steinbach K, et al. Neutralization of the IL-17 axis diminishes neutrophil invasion and protects from ischemic stroke. Blood (2012) 120(18):3793-802. doi:10.1182/blood-2012-02-412726

9. Kleinschnitz C, Schwab N, Kraft P, Hagedorn I, Dreykluft A, Schwarz T, et al. Early detrimental T-Cell effects in experimental cerebral ischemia are 
neither related to adaptive immunity nor thrombus formation. Blood (2010) 115(18):3835-42. doi:10.1182/blood-2009-10-249078

10. Kleinschnitz C, Kraft P, Dreykluft A, Hagedorn I, Göbel K, Schuhmann MK, et al. Regulatory $\mathrm{T}$ cells are strong promoters of acute ischemic stroke in mice by inducing dysfunction of the cerebral microvasculature. Blood (2013) 121(4):679-91. doi:10.1182/blood-2012-04-426734

11. Yilmaz G, Granger DN. Cell adhesion molecules and ischemic stroke. Neurol Res (2008) 30(8):783-93. doi:10.1179/174313208X341085

12. Yilmaz G, Arumugam TV, Stokes KY, Granger DN. Role of T lymphocytes and interferon-gamma in ischemic stroke. Circulation (2006) 113(17):2105-12. doi:10.1161/CIRCULATIONAHA.105.593046

13. Shichita T, Sugiyama Y, Ooboshi H, Sugimori H, Nakagawa R, Takada I, et al. Pivotal role of cerebral interleukin-17-producing gammadeltaT cells in the delayed phase of ischemic brain injury. Nat Med (2009) 15(8):946-50. doi:10.1038/nm.1999

14. Melani A, Turchi D, Vannucchi MG, Cipriani S, Gianfriddo M, Pedata F. ATP extracellular concentrations are increased in the rat striatum during in vivo ischemia. Neurochem Int (2005) 47(6):442-8. doi:10.1016/j. neuint.2005.05.014

15. Cavaliere F, Dinkel K, Reymann K. Microglia response and P2 receptor participation in oxygen/glucose deprivation-induced cortical damage. Neuroscience (2005) 136(3):615-23. doi:10.1016/j.neuroscience.2005.04.038

16. Kim JY, Yenari MA. The immune modulating properties of the heat shock proteins after brain injury. Anat Cell Biol (2013) 46(1):1-7. doi:10.5115/ acb.2013.46.1.1

17. Kim J-B, Choi JS, Yu Y-M, Nam K, Piao C-S, Kim S-W, et al. HMGB1, a novel cytokine-like mediator linking acute neuronal death and delayed neuroinflammation in the postischemic brain. J Neurosci (2006) 26(24):6413-21. doi:10.1523/JNEUROSCI.3815-05.2006

18. Schilling M, Besselmann M, Leonhard C, Mueller M, Ringelstein EB, Kiefer R. Microglial activation precedes and predominates over macrophage infiltration in transient focal cerebral ischemia: a study in green fluorescent protein transgenic bone marrow chimeric mice. Exp Neurol (2003) 183(1):25-33. doi:10.1016/S0014-4886(03)00082-7

19. Gelderblom M, Leypoldt F, Steinbach K, Behrens D, Choe CU, Siler DA, et al. Temporal and spatial dynamics of cerebral immune cell accumulation in stroke. Stroke (2009) 40(5):1849-57. doi:10.1161/STROKEAHA.108.534503

20. Clausen BH, Lambertsen KL, Babcock AA, Holm TH, Dagnaes-Hansen F, Finsen B. Interleukin-1beta and tumor necrosis factor-alpha are expressed by different subsets of microglia and macrophages after ischemic stroke in mice. J Neuroinflammation (2008) 5(1):46. doi:10.1186/1742-2094-5-46

21. Caso JR, Pradillo JM, Hurtado O, Lorenzo P, Moro MA, Lizasoain I. Toll-like receptor 4 is involved in brain damage and inflammation after experimental stroke. Circulation (2007) 115(12):1599-608. doi:10.1161/ CIRCULATIONAHA.106.603431

22. Lehnardt S, Lehmann S, Kaul D, Tschimmel K, Hoffmann O, Cho S, et al. Toll-like receptor 2 mediates CNS injury in focal cerebral ischemia. J Neuroimmunol (2007) 190(1-2):28-33. doi:10.1016/j.jneuroim.2007.07.023

23. Tang SC, Yeh SJ, Li YI, Wang YC, Baik SH, Santro T, et al. Evidence for a detrimental role of TLR8 in ischemic stroke. Exp Neurol (2013) 250:341-7. doi:10.1016/j.expneurol.2013.10.012

24. Fann DY-W, Lee S-Y, Manzanero S, Tang S-C, Gelderblom M, Chunduri P, et al. Intravenous immunoglobulin suppresses NLRP1 and NLRP3 inflammasome-mediated neuronal death in ischemic stroke. Cell Death Dis (2015) 4(9):e790. doi:10.1038/cddis.2013.326

25. Ito M, Shichita T, Okada M, Komine R, Noguchi Y, Yoshimura A, et al. Bruton's tyrosine kinase is essential for NLRP3 inflammasome activation and contributes to ischaemic brain injury. Nat Commun (2015) 6:7360. doi: $10.1038 /$ ncomms 8360

26. Domercq M, Perez-Samartin A, Aparicio D, Alberdi E, Pampliega O, Matute C. P2X7 receptors mediate ischemic damage to oligodendrocytes. Glia (2010) 58(6):730-40. doi:10.1002/glia.20958

27. Chu K, Yin B, Wang J, Peng G, Liang H, Xu Z, et al. Inhibition of P2X7 receptor ameliorates transient global cerebral ischemia/reperfusion injury via modulating inflammatory responses in the rat hippocampus. J Neuroinflammation (2012) 9:69. doi:10.1186/1742-2094-9-69

28. Konsman JP, Drukarch B, Van Dam A-M. (Peri)Vascular production and action of pro-inflammatory cytokines in brain pathology. Clin Sci (2007) 112(1):1-25. doi:10.1042/CS20060043
29. Crow AR, Suppa SJ, Chen X, Mott PJ, Lazarus AH. The neonatal Fc receptor $(\mathrm{FcRn})$ is not required for IVIg or anti-CD44 monoclonal antibodymediated amelioration of murine immune thrombocytopenia. Blood (2011) 118(24):6403-6. doi:10.1182/blood-2011-08-374223

30. Liesz A, Zhou W, Mracsko E, Karcher S, Bauer H, Schwarting S, et al. Inhibition of lymphocyte trafficking shields the brain against deleterious neuroinflammation after stroke. Brain (2011) 134(3):704-20. doi:10.1093/ brain/awr008

31. Clarkson BDS, Ling C, Shi Y, Harris MG, Rayasam A, Sun D, et al. T cellderived interleukin (IL)-21 promotes brain injury following stroke in mice. J Exp Med (2014) 211(4):595-604. doi:10.1084/jem.20131377

32. Liesz A, Suri-Payer E, Veltkamp C, Doerr H, Sommer C, Rivest S, et al. Regulatory $\mathrm{T}$ cells are key cerebroprotective immunomodulators in acute experimental stroke. Nat Med (2009) 15(2):192-9. doi:10.1038/nm.1927

33. Liesz A, Zhou W, Na SY, Hämmerling GJ, Garbi N, Karcher S, et al. Boosting regulatory $\mathrm{T}$ cells limits neuroinflammation in permanent cortical stroke. J Neurosci (2013) 33(44):17350-62. doi:10.1523/JNEUROSCI.4901-12.2013

34. Ren X, Akiyoshi K, Vandenbark AA, Hurn PD, Offner H. CD4+FoxP3+ regulatory T-cells in cerebral ischemic stroke. Metab Brain Dis (2010) 26(1):87-90. doi:10.1007/s11011-010-9226-6

35. Ludewig P, Gallizioli M, Urra X, Behr S, Brait VH, Gelderblom M, et al. Dendritic cells in brain diseases. Biochim Biophys Acta (2015) 1862(3):352-67. doi:10.1016/j.bbadis.2015.11.003

36. Murikinati S, Juttler E, Keinert T, Ridder DA, Muhammad S, Waibler Z, et al. Activation of cannabinoid 2 receptors protects against cerebral ischemia by inhibiting neutrophil recruitment. FASEB J (2010) 24(3):788-98. doi:10.1096/f.09-141275

37. Jickling GC, Liu D, Ander BP, Stamova B, Zhan X, Sharp FR. Targeting neutrophils in ischemic stroke: translational insights from experimental studies. J Cereb Blood Flow Metab (2015) 35(6):888-901. doi:10.1038/jcbfm.2015.45

38. Meisel C, Meisel A. Suppressing immunosuppression after stroke. N Engl J Med (2011) 365(22):2134-6. doi:10.1056/NEJMcibr1112454

39. Klehmet J, Harms H, Richter M, Prass K, Volk HD, Dirnagl U, et al. Strokeinduced immunodepression and post-stroke infections: lessons from the preventive antibacterial therapy in stroke trial. Neuroscience (2009) 158(3):1184-93. doi:10.1016/j.neuroscience.2008.07.044

40. McCulloch L, Smith CJ, McColl BW. Adrenergic-mediated loss of splenic marginal zone B cells contributes to infection susceptibility after stroke. Nat Commun (2017) 8:15051. doi:10.1038/ncomms15051

41. Liesz A, Roth S, Zorn M, Sun L, Hofmann K, Veltkamp R. Acquired immunoglobulin $\mathrm{G}$ deficiency in stroke patients and experimental brain ischemia. Exp Neurol (2015) 271:46-52. doi:10.1016/j.expneurol.2015.04.021

42. Denes A, Vidyasagar R, Feng J, Narvainen J, McColl BW, Kauppinen RA, et al. Proliferating resident microglia after focal cerebral ischaemia in mice. J Cereb Blood Flow Metab (2007) 27(12):1941-53. doi:10.1038/sj.jcbfm. 9600495

43. Huynh M-LN, Fadok VA, Henson PM. Phosphatidylserine-dependent ingestion of apoptotic cells promotes TGF-betal secretion and the resolution of inflammation. J Clin Invest (2002) 109(1):41-50. doi:10.1172/JCI11638

44. Voll RE, Herrmann M, Roth EA, Stach C, Kalden JR, Girkontaite I. Immunosuppressive effects of apoptotic cells. Nature (1997) 390(6658): 350-1. doi:10.1038/37022

45. Li S, Overman JJ, Katsman D, Kozlov SV, Donnelly CJ, Twiss JL, et al. An age-related sprouting transcriptome provides molecular control of axonal sprouting after stroke. Nat Neurosci (2010) 13(12):1496-504. doi:10.1038/ nn. 2674

46. Wang Y, Kilic E, Kilic U, Weber B, Bassetti CL, Marti HH, et al. VEGF overexpression induces post-ischaemic neuroprotection, but facilitates haemodynamic steal phenomena. Brain (2005) 128(Pt 1):52-63. doi:10.1093/ brain/awh325

47. Ludewig P, Sedlacik J, Gelderblom M, Bernreuther C, Korkusuz Y, Wagener C, et al. CEACAM1 inhibits MMP-9-mediated blood-brainbarrier breakdown in a mouse model for ischemic stroke. Circ Res (2013) 113:1013-22. doi:10.1161/CIRCRESAHA.113.301207

48. Zhao BQ, Wang S, Kim HY, Storrie H, Rosen BR, Mooney DJ, et al. Role of matrix metalloproteinases in delayed cortical responses after stroke. Nat Med (2006) 12(4):441-5. doi:10.1038/nm1387

49. Baird AE, Benfield A, Schlaug G, Siewert B, Lövblad KO, Edelman RR, et al. Enlargement of human cerebral ischemic lesion volumes measured 
by diffusion-weighted magnetic resonance imaging. Ann Neurol (1997) 41(5):581-9. doi:10.1002/ana.410410506

50. Schlaug G, Benfield A, Baird AE, Siewert B, Lövblad KO, Parker RA, et al. The ischemic penumbra: operationally defined by diffusion and perfusion MRI. Neurology (1999) 53(7):1528-37. doi:10.1212/WNL.53.7.1528

51. Akopov SE, Simonian NA, Grigorian GS. Dynamics of polymorphonuclear leukocyte accumulation in acute cerebral infarction and their correlation with brain tissue damage. Stroke (1996) 27(10):1739-43. doi:10.1161/01. STR.27.10.1739

52. Price CJS, Menon DK, Peters AM, Ballinger JR, Barber RW, Balan KK, et al. Cerebral neutrophil recruitment, histology, and outcome in acute ischemic stroke: an imaging-based study. Stroke (2004) 35(7):1659-64. doi:10.1161/01. STR.0000130592.71028.92

53. Jander S, Schroeter M, Saleh A. Imaging inflammation in acute brain ischemia. Stroke (2007) 38(2 Suppl):642-5. doi:10.1161/01.STR.0000250048.42916.ad

54. Thiel A, Heiss W-D. Imaging of microglia activation in stroke. Stroke (2011) 42(2):507-12. doi:10.1161/STROKEAHA.110.598821

55. Mena H, Cadavid D, Rushing EJ. Human cerebral infarct: a proposed histopathologic classification based on 137 cases. Acta Neuropathol (2004) 108(6):524-30. doi:10.1007/s00401-004-0918-z

56. Yilmaz A, Fuchs T, Dietel B, Altendorf R, Cicha I, Stumpf C, et al. Transient decrease in circulating dendritic cell precursors after acute stroke: potential recruitment into the brain. Clin Sci (Lond) (2010) 118(2):147-57. doi:10.1042/ CS20090154

57. Arsene D, Vasilescu F, Toader C, Bălan A, Popa C, Ardeleanu C. Clinicopathological correlations in fatal ischemic stroke. An immunohistochemical study of human brain penumbra. Rom J Morphol Embryol (2011) 52(1):29-38.

58. Wu H, Zhang Z, Hu X, Zhao R, Song Y, Ban X, et al. Dynamic changes of inflammatory markers in brain after hemorrhagic stroke in humans: a postmortem study. Brain Res (2010) 1342:111-7. doi:10.1016/j.brainres.2010.04.033

59. Li G-Z, Zhong D, Yang L-M, Sun B, Zhong Z-H, Yin Y-H, et al. Expression of interleukin-17 in ischemic brain tissue. Scand J Immunol (2005) 62(5):481-6. doi:10.1111/j.1365-3083.2005.01683.x

60. Kostulas N, Pelidou SH, Kivisäkk P, Kostulas V, Link H. Increased IL-1beta, IL-8, and IL-17 mRNA expression in blood mononuclear cells observed in a prospective ischemic stroke study. Stroke (1999) 30(10):2174-9. doi:10.1161/01.STR.30.10.2174

61. Minnerup J, Sutherland BA, Buchan AM, Kleinschnitz C. Neuroprotection for stroke: current status and future perspectives. Int J Mol Sci (2012) 13(12):11753-72. doi:10.3390/ijms130911753

62. Mestas J, Hughes CCW. Of mice and not men: differences between mouse and human immunology. J Immunol (2004) 172(5):2731-8. doi:10.4049/ jimmunol.172.5.2731

63. Barone FC, Knudsen DJ, Nelson AH, Feuerstein GZ, Willette RN. Mouse strain differences in susceptibility to cerebral ischemia are related to cerebral vascular anatomy. J Cereb Blood Flow Metab (1993) 13(4):683-92. doi:10.1038/jcbfm.1993.87

64. Hecht NN. Entwicklung Eines Modells Zur Chronisch Zerebralen Ischämie Bei Der C57/BL6 Maus. Berlin: Südwestdetuscher Verlag für Hochschulschriften (2008).

65. O'Collins VE, Macleod MR, Donnan GA, Horky LL, van der Worp BH, Howells DW. 1,026 experimental treatments in acute stroke. Ann Neurol (2006) 59(3):467-77. doi:10.1002/ana.20741

66. Langhauser F, Kraft P, Göb E, Leinweber J. Blocking of A4 integrin does not protect from acute ischemic stroke in mice. Stroke (2014) 45(6):1799-806. doi:10.1161/STROKEAHA.114.005000

67. Relton JK, Sloan KE, Frew EM, Whalley ET, Adams SP. Inhibition of A4 integrin protects against transient focal cerebral ischemia in normotensive and hypertensive rats. Stroke (2001) 32(1):199-205. doi:10.1161/01.STR.32. 1.199

68. Becker K, Kindrick D, Relton J, Harlan J, Winn R. Antibody to the alpha4 Integrin decreases infarct size in transient focal cerebral ischemia in rats. Stroke (2001) 32(1):206-11. doi:10.1161/01.STR.32.1.206

69. Llovera G, Hofmann K, Roth S, Salas-Pérdomo A, Ferrer-Ferrer M, Perego C, et al. Results of a preclinical randomized controlled multicenter trial (pRCT): anti-CD49d treatment for acute brain ischemia. Sci Transl Med (2015) 7(299):299ra121. doi:10.1126/scitranslmed.aaa9853

70. Elkins J, Veltkamp R, Montaner J, Johnston SC, Singhal AB, Becker K, et al. Safety and efficacy of natalizumab in patients with acute ischaemic stroke
(ACTION): a randomised, placebo-controlled, double-blind phase 2 trial. Lancet Neurol (2017) 16(3):217-26. doi:10.1016/S1474-4422(16)30357-X

71. Kraft P, Göb E, Schuhmann MK, Göbel K, Deppermann C, Thielmann I, et al. FTY720 ameliorates acute ischemic stroke in mice by reducing thromboinflammation but not by direct neuroprotection. Stroke (2013) 44(11):320210. doi:10.1161/STROKEAHA.113.002880

72. Czech B, Pfeilschifter W, Mazaheri-Omrani N, Strobel MA, Kahles T, Neumann-Haefelin T, et al. The immunomodulatory sphingosine 1-phosphate analog FTY720 reduces lesion size and improves neurological outcome in a mouse model of cerebral ischemia. Biochem Biophys Res Commun (2009) 389(2):251-6. doi:10.1016/j.bbrc.2009.08.142

73. Hasegawa Y, Suzuki H, Sozen T, Rolland W, Zhang JH. Activation of sphingosine 1-phosphate receptor-1 by FTY720 is neuroprotective after ischemic stroke in rats. Stroke (2010) 41(2):368-74. doi:10.1161/ STROKEAHA.109.568899

74. Wei Y, Yemisci M, Kim HH, Yung LM, Shin HK, Hwang SK, et al. Fingolimod provides long-term protection in rodent models of cerebral ischemia. Ann Neurol (2010) 69(1):119-29. doi:10.1002/ana.22186

75. Liesz A, Sun L, Zhou W, Schwarting S, Mracsko E, Zorn M, et al. FTY720 reduces post-ischemic brain lymphocyte influx but does not improve outcome in permanent murine cerebral ischemia. PLoS One (2011) 6(6):e21312. doi:10.1371/journal.pone.0021312

76. Fu Y, Zhang N, Ren L, Yan Y, Sun N, Li Y-J, et al. Impact of an immune modulator fingolimod on acute ischemic stroke. Proc Natl Acad Sci U S A (2014) 111(51):18315-20. doi:10.1073/pnas.1416166111

77. Zhu Z, Fu Y, Tian D, Sun N, Han W, Chang G, et al. Combination of the immune modulator fingolimod with alteplase in acute ischemic stroke a pilot trial. Circulation (2015) 132(12):1104-12. doi:10.1161/ CIRCULATIONAHA.115.016371/-/DC1

78. Nimmerjahn F, Ravetch JV. Fcy receptors as regulators of immune responses. Nat Rev Immunol (2008) 8(1):34-47. doi:10.1038/nri2206

79. Takai T, Li M, Sylvestre D, Clynes R, Ravetch JV. FcR gamma chain deletion results in pleiotrophic effector cell defects. Cell (1994) 76(3):519-29. doi:10.1016/0092-8674(94)90115-5

80. Nimmerjahn F, Ravetch JV. Fcgamma receptors: old friends and new family members. Immunity (2006) 24(1):19-28. doi:10.1016/j.immuni.2005.11.010

81. Nimmerjahn F, Bruhns P, Horiuchi K, Ravetch JV. FcgammaRIV: a novel FcR with distinct IgG subclass specificity. Immunity (2005) 23(1):41-51. doi:10.1016/j.immuni.2005.05.010

82. van der Poel CE, Spaapen RM, van de Winkel JGJ, Leusen JHW. Functional characteristics of the high affinity IgG receptor, Fc $\gamma$ RI. J Immunol (2011) 186(5):2699-704. doi:10.4049/jimmunol.1003526

83. Roopenian DC, Akilesh S. FcRn: the neonatal Fc receptor comes of age. Nat Rev Immunol (2007) 7(9):715-25. doi:10.1038/nri2155

84. Mócsai A, Ruland J, Tybulewicz VLJ. The SYK tyrosine kinase: a crucial player in diverse biological functions. Nat Rev Immunol (2010) 10(6):387-402. doi: $10.1038 /$ nri2765

85. Ono M, Bolland S, Tempst P, Ravetch JV. Role of the inositol phosphatase SHIP in negative regulation of the immune system by the receptor $\mathrm{Fc}$ (gamma) RIIB. Nature (1996) 383(6597):263-6. doi:10.1038/383263a0

86. Bolland S, Ravetch JV. Spontaneous autoimmune disease in Fc(gamma) RIIB-deficient mice results from strain-specific epistasis. Immunity (2000) 13(2):277-85. doi:10.1016/S1074-7613(00)00027-3

87. Kleinau S, Martinsson P, Heyman B. Induction and suppression of collagen-induced arthritis is dependent on distinct Fcy receptors. J Exp Med (2000) 191(9):1611-6. doi:10.1084/jem.191.9.1611

88. Kaneko Y, Nimmerjahn F, Madaio MP, Ravetch JV. Pathology and protection in nephrotoxic nephritis is determined by selective engagement of specific $\mathrm{Fc}$ receptors. J Exp Med (2006) 203(3):789-97. doi:10.1084/jem.20051900

89. Szalai AJ, Hu X, Raman C, Barnum SR. Requirement of the Fc receptor common $\gamma$-chain for $\gamma \delta \mathrm{T}$ cell-mediated promotion of murine experimental autoimmune encephalomyelitis. Eur J Immunol (2005) 35(12):3487-92. doi:10.1002/eji.200535285

90. van Montfoort N, 't Hoen PAC, Mangsbo SM, Camps MGM, Boross P, Melief CJM, et al. Fcy receptor IIb strongly regulates Fcy receptorfacilitated T cell activation by dendritic cells. J Immunol (2012) 189(1):92101. doi:10.4049/jimmunol.1103703

91. Pritchard NR, Cutler AJ, Uribe S, Chadban SJ, Morley BJ, Smith KG. Autoimmune-prone mice share a promoter haplotype associated with 
reduced expression and function of the Fc receptor FcgammaRII. Curr Biol (2000) 10(4):227-30. doi:10.1016/S0960-9822(00)00344-4

92. Hida S, Yamasaki S, Sakamoto Y, Takamoto M, Obata K, Takai T, et al. Fc receptor gamma-chain, a constitutive component of the IL-3 receptor, is required for IL-3-induced IL-4 production in basophils. Nat Immunol (2009) 10(2):214-22. doi:10.1038/ni.1686

93. Bruhns P. Properties of mouse and human IgG receptors and their contribution to disease models. Blood (2012) 119(24):5640-9. doi:10.1182/ blood-2012-01-380121

94. Bruhns P, Iannascoli B, England P, Mancardi DA. Specificity and affinity of human Fcy receptors and their polymorphic variants for human IgG subclasses. Blood (2009) 113(16):3716-25. doi:10.1182/blood-2008-09179754

95. Lehrnbecher T, Foster CB, Zhu S, Leitman SF. Variant genotypes of the low-affinity $\mathrm{Fc} \gamma$ receptors in two control populations and a review of lowaffinity Fcy receptor polymorphisms in control and disease. Blood (1999) 94(12):4220-32.

96. Takai T. Roles of Fc receptors in autoimmunity. Nat Rev Immunol (2002) 2(8):580-92. doi:10.1038/nri856

97. Schwab I, Nimmerjahn F. Intravenous immunoglobulin therapy: how does IgG modulate the immune system? Nat Rev Immunol (2013) 13(3):176-89. doi:10.1038/nri3401

98. Debré M, Bonnet MC, Fridman WH, Carosella E, Philippe N, Reinert P, et al. Infusion of $\mathrm{Fc}$ gamma fragments for treatment of children with acute immune thrombocytopenic purpura. Lancet (1993) 342(8877):945-9. doi:10.1016/0140-6736(93)92000-J

99. Samuelsson A, Towers TL, Ravetch JV. Anti-inflammatory activity of IVIG mediated through the inhibitory Fc receptor. Science (2001) 291(5503):484-6. doi:10.1126/science.291.5503.484

100. Nimmerjahn F, Ravetch JV. Antibody-mediated modulation of immune responses. Immunol Rev (2010) 236(1):265-75. doi:10.1111/j.1600065X.2010.00910.x

101. Basta M, Kirshbom P, Frank MM, Fries LF. Mechanism of therapeutic effect of high-dose intravenous immunoglobulin. Attenuation of acute, complement-dependent immune damage in a guinea pig model. J Clin Invest (1989) 84(6):1974-81. doi:10.1172/JCI114387

102. Brownlie RJ, Lawlor KE, Niederer HA, Cutler AJ, Xiang Z, Clatworthy MR, et al. Distinct cell-specific control of autoimmunity and infection by FcgammaRIIb. J Exp Med (2008) 205(4):883-95. doi:10.1084/jem.20072565

103. Kang Y-S, Yamazaki S, Iyoda T, Pack M, Bruening SA, Kim JY, et al. SIGN-R1, a novel C-type lectin expressed by marginal zone macrophages in spleen, mediates uptake of the polysaccharide dextran. Int Immunol (2003) 15(2):177-86. doi:10.1093/intimm/dxg019

104. Kaneko Y, Nimmerjahn F, Ravetch JV. Anti-inflammatory activity of immunoglobulin G resulting from Fc sialylation. Science (2006) 313(5787):670-3. doi:10.1126/science.1129594

105. Conde P, Rodriguez M, van der Touw W, Jimenez A, Burns M, Miller J, et al. DC-SIGN(+) macrophages control the induction of transplantation tolerance. Immunity (2015) 42(6):1143-58. doi:10.1016/j.immuni.2015.05.009

106. Chang BY, Huang MM, Francesco M, Chen J, Sokolove J, Magadala P, et al. The Bruton tyrosine kinase inhibitor PCI-32765 ameliorates autoimmune arthritis by inhibition of multiple effector cells. Arthritis Res Ther (2011) 13(4):R115. doi:10.1186/ar3400

107. Blank M, Anafi L, Zandman-Goddard G, Krause I, Goldman S, Shalev E, et al. The efficacy of specific IVIG anti-idiotypic antibodies in antiphospholipid syndrome (APS): trophoblast invasiveness and APS animal model. Int Immunol (2007) 19(7):857-65. doi:10.1093/intimm/dxm052

108. Viard I, Wehrli P, Bullani R, Schneider P, Holler N, Salomon D, et al. Inhibition of toxic epidermal necrolysis by blockade of CD95 with human intravenous immunoglobulin. Science (1998) 282(5388):490-3. doi:10.1126/ science. 282.5388 .490

109. Svenson M, Hansen MB, Ross C, Diamant M, Rieneck K, Nielsen H, et al. Antibody to granulocyte-macrophage colony-stimulating factor is a dominant anti-cytokine activity in human IgG preparations. Blood (1998) 91(6):2054-61.

110. MacMillan HF, Lee T, Issekutz AC. Intravenous immunoglobulin G-mediated inhibition of T-cell proliferation reflects an endogenous mechanism by which IgG modulates T-cell activation. Clin Immunol (2009) 132(2):222-33. doi:10.1016/j.clim.2009.04.002
111. Maddur MS, Vani J, Hegde P, Lacroix-Desmazes S, Kaveri SV, Bayry J. Inhibition of differentiation, amplification, and function of human TH17 cells by intravenous immunoglobulin. JAllergy Clin Immunol (2011) 127(3):823-30.e1-7. doi:10.1016/j.jaci.2010.12.1102

112. Graphou O, Chioti A, Pantazi A, Tsekoura C, Kontopoulou V, Georgiadou E, et al. Effect of intravenous immunoglobulin treatment on the Th1/Th2 balance in women with recurrent spontaneous abortions. Am J Reprod Immunol (2003) 49(1):21-9. doi:10.1034/j.1600-0897.2003.01169.x

113. Mouzaki A, Theodoropoulou M, Gianakopoulos I, Vlaha V, Kyrtsonis MC, Maniatis A. Expression patterns of Th1 and Th2 cytokine genes in childhood idiopathic thrombocytopenic purpura (ITP) at presentation and their modulation by intravenous immunoglobulin G (IVIg) treatment: their role in prognosis. Blood (2002) 100(5):1774-9.

114. Kessel A, Ammuri H, Peri R, Pavlotzky ER, Blank M, Shoenfeld Y, et al. Intravenous immunoglobulin therapy affects $\mathrm{T}$ regulatory cells by increasing their suppressive function. J Immunol (2007) 179(8):5571-5. doi:10.4049/ jimmunol.179.8.5571

115. De Groot AS, Moise L, McMurry JA, Wambre E, Van Overtvelt L, Moingeon $P$, et al. Activation of natural regulatory $\mathrm{T}$ cells by $\mathrm{IgG}$ Fc-derived peptide 'tregitopes'. Blood (2008) 112(8):3303-11. doi:10.1182/ blood-2008-02-138073

116. Schwab I, Seeling M, Biburger M, Aschermann S, Nitschke L, Nimmerjahn F. $\mathrm{B}$ cells and $\mathrm{CD} 22$ are dispensable for the immediate antiinflammatory activity of intravenous immunoglobulins in vivo. Eur J Immunol (2012) 42(12):3302-9. doi:10.1002/eji.201242710

117. Andersson J, Skansén-Saphir U, Sparrelid E, Andersson U. Intravenous Immune globulin affects cytokine production in $\mathrm{T}$ lymphocytes and monocytes/macrophages. Clin Exp Immunol (1996) 104(Suppl 1):10-20.

118. van der Kleij H, Charles N, Karimi K, Mao YK, Foster J, Janssen L, et al. Evidence for neuronal expression of functional Fc (epsilon and gamma) receptors. J Allergy Clin Immunol (2010) 125(3):757-60. doi:10.1016/j. jaci.2009.10.054

119. Qu L, Zhang P, LaMotte RH, Ma C. Neuronal Fc-gamma receptor I mediated excitatory effects of IgG immune complex on rat dorsal root ganglion neurons. Brain Behav Immun (2011) 25(7):1399-407. doi:10.1016/j.bbi.2011.04.008

120. Congdon EE, Gu J, Sait HBR, Sigurdsson EM. Antibody uptake into neurons occurs primarily via clathrin-dependent $\mathrm{F} c \gamma$ receptor endocytosis and is a prerequisite for acute tau protein clearance. J Biol Chem (2013) 288(49):35452-65. doi:10.1074/jbc.M113.491001

121. Fernandez-Vizarra P, Lopez-Franco O, Mallavia B, Higuera-Matas A, Lopez-Parra V, Ortiz-Muñoz G, et al. Immunoglobulin G Fc receptor deficiency prevents Alzheimer-like pathology and cognitive impairment in mice. Brain (2012) 135(Pt 9):2826-37. doi:10.1093/brain/aws195

122. Kam T-I, Song S, Gwon Y, Park H, Yan J-J, Im I, et al. FcyRIIb mediates amyloid-B neurotoxicity and memory impairment in Alzheimer's disease. J Clin Invest (2013) 123(7):2791-802. doi:10.1172/JCI66827

123. Nakamura K, Hirai H, Torashima T, Miyazaki T, Tsurui H, Xiu Y, et al. CD3 and immunoglobulin G Fc receptor regulate cerebellar functions. Mol Cell Biol (2007) 27(14):5128-34. doi:10.1128/MCB.01072-06

124. Vedeler C, Ulvestad E, Grundt I, Conti G, Nyland H, Matre R, et al. Fc receptor for IgG (FcR) on rat microglia. J Neuroimmunol (1994) 49(1-2):19-24. doi:10.1016/0165-5728(94)90176-7

125. Ulvestad E, Williams K, Vedeler C, Antel J, Nyland H, Mørk S, et al. Reactive microglia in multiple sclerosis lesions have an increased expression of receptors for the Fc part of IgG. J Neurol Sci (1994) 121(2):125-31. doi:10.1016/0022-510X(94)90340-9

126. Teeling JL, Carare RO, Glennie MJ, Perry VH. Intracerebral immune complex formation induces inflammation in the brain that depends on $\mathrm{Fc}$ receptor interaction. Acta Neuropathol (2012) 124(4):479-90. doi:10.1007/ s00401-012-0995-3

127. Loughlin AJ, Woodroofe MN, Cuzner ML. Modulation of interferon-gammainduced major histocompatibility complex class II and Fc receptor expression on isolated microglia by transforming growth factor-beta 1, interleukin-4, noradrenaline and glucocorticoids. Immunology (1993) 79(1):125-30.

128. Loughlin AJ, Woodroofe MN, Cuzner ML. Regulation of Fc receptor and major histocompatibility complex antigen expression on isolated rat microglia by tumour necrosis factor, interleukin- 1 and lipopolysaccharide: effects on interferon-gamma induced activation. Immunology (1992) 75(1): $170-5$. 
129. Song X, Shapiro S, Goldman DL. Fc $\gamma$ receptor I- and III-mediated macrophage inflammatory protein $1 \alpha$ induction in primary human and murine microglia. Infect Immun (2002) 70(9):5177-84. doi:10.1128/IAI.70.9.5177-5184. 2002

130. Lunnon K, Teeling JL, Tutt AL, Cragg MS, Glennie MJ, Perry VH. Systemic inflammation modulates $\mathrm{Fc}$ receptor expression on microglia during chronic neurodegeneration. J Immunol (2011) 186(12):7215-24. doi:10.4049/ jimmunol.0903833

131. Zotova E, Bharambe V, Cheaveau M, Morgan W, Holmes C, Harris S, et al. Inflammatory components in human Alzheimer's disease and after active amyloid-\$42 immunization. Brain (2013) 136(Pt 9):2677-96. doi:10.1093/ brain/awt 210

132. Li Y-N, Qin X-J, Kuang F, Wu R, Duan X-L, Ju G, et al. Alterations of Fc gamma receptor I and toll-like receptor 4 mediate the antiinflammatory actions of microglia and astrocytes after adrenaline-induced blood-brain barrier opening in rats. J Neurosci Res (2008) 86(16):3556-65. doi:10.1002/ jnr. 21810

133. Nitta T, Yagita H, Sato K, Okumura K. Expression of Fc gamma receptors on astroglial cell lines and their role in the central nervous system. Neurosurgery (1992) 31(1):83-7; discussion 87-8. doi:10.1097/00006123-199207000-00012

134. Nakahara J, Tan-Takeuchi K, Seiwa C, Gotoh M, Kaifu T, Ujike A, et al. Signaling via immunoglobulin $\mathrm{Fc}$ receptors induces oligodendrocyte precursor cell differentiation. Dev Cell (2003) 4(6):841-52. doi:10.1016/ S1534-5807(03)00155-2

135. Lünemann JD, Nimmerjahn F, Dalakas MC. Intravenous immunoglobulin in neurology - mode of action and clinical efficacy. Nat Rev Neurol (2015) 11(2):80-9. doi:10.1038/nrneurol.2014.253

136. Mendell JR, Barohn RJ, Freimer ML, Kissel JT, King W, Nagaraja HN, et al. Randomized controlled trial of IVIg in untreated chronic inflammatory demyelinating polyradiculoneuropathy. Neurology (2001) 56(4):445-9. doi:10.1212/WNL.56.4.445

137. Hughes RAC, Donofrio P, Bril V, Dalakas MC, Deng C, Hanna K, et al. Intravenous immune globulin (10\% caprylate-chromatography purified) for the treatment of chronic inflammatory demyelinating polyradiculoneuropathy (ICE study): a randomised placebo-controlled trial. Lancet Neurol (2008) 7(2):136-44. doi:10.1016/S1474-4422(07)70329-0

138. Yan WX, Taylor J, Andrias-Kauba S, Pollard JD. Passive transfer of demyelination by serum or IgG from chronic inflammatory demyelinating polyneuropathy patients. Ann Neurol (2000) 47(6):765-75. doi:10.1002/1531-8249(200006)47:6<765::AID-ANA9>3.3.CO;2-\#

139. Salomon B, Rhee L, Bour-Jordan H, Hsin H, Montag A, Soliven B, et al. Development of spontaneous autoimmune peripheral polyneuropathy in B7-2-deficient NOD mice. J Exp Med (2001) 194(5):677-84. doi:10.1084/ jem.194.5.677

140. Tackenberg B, Jelcic I, Baerenwaldt A, Oertel WH, Sommer N, Nimmerjahn F, et al. Impaired inhibitory Fcgamma receptor IIB expression on B cells in chronic inflammatory demyelinating polyneuropathy. Proc Natl Acad Sci U S A (2009) 106(12):4788-92. doi:10.1073/pnas.0807319106

141. Nikolova KA, Tchorbanov AI, Djoumerska-Alexieva IK, Nikolova M, Vassilev TL. Intravenous immunoglobulin up-regulates the expression of the inhibitory FcgammaIIB receptor on B cells. Immunol Cell Biol (2009) 87(7):529-33. doi:10.1038/icb.2009.36

142. van Doorn PA, Ruts L, Jacobs BC. Clinical features, pathogenesis, and treatment of Guillain-Barré syndrome. Lancet Neurol (2008) 7(10):939-50. doi:10.1016/S1474-4422(08)70215-1

143. Dalakas MC. Blockade of blocking antibodies in Guillain-Barré syndromes: 'unblocking' the mystery of action of intravenous immunoglobulin. Ann Neurol (2002) 51(6):667-9. doi:10.1002/ana.10259

144. Achiron A, Gilad R, Margalit R, Gabbay U, Sarova-Pinhas I, Cohen IR, et al. Intravenous gammaglobulin treatment in multiple sclerosis and experimental autoimmune encephalomyelitis: delineation of usage and mode of action. J Neurol (1994) 57(Suppl):57-61.

145. Deane R, Sagare A, Hamm K, Parisi M, LaRue B, Guo H, et al. IgG-assisted age-dependent clearance of Alzheimer's amyloid beta peptide by the bloodbrain barrier neonatal Fc receptor. J Neurosci (2005) 25(50):11495-503. doi:10.1523/JNEUROSCI.3697-05.2005

146. Schlachetzki F, Zhu C, Pardridge WM. Expression of the neonatal Fc receptor (FcRn) at the blood-brain barrier. J Neurochem (2002) 81(1):203-6. doi:10.1046/j.1471-4159.2002.00840.x
147. Widiapradja A, Vegh V, Lok KZ, Manzanero S, Thundyil J, Gelderblom M, et al. Intravenous immunoglobulin protects neurons against amyloid beta-peptide toxicity and ischemic stroke by attenuating multiple cell death pathways. J Neurochem (2012) 122(2):321-32. doi:10.1111/j.1471-4159.2012.07754.x

148. Arumugam TV, Tang S-C, Lathia JD, Cheng A, Mughal MR, Chigurupati S, et al. Intravenous immunoglobulin (IVIG) protects the brain against experimental stroke by preventing complement-mediated neuronal cell death. Proc Natl Acad Sci U S A (2007) 104(35):14104-9. doi:10.1073/pnas.0700506104

149. St-Amour I, Paré I, Alata W, Coulombe K, Ringuette-Goulet C, DrouinOuellet J, et al. Brain bioavailability of human intravenous immunoglobulin and its transport through the murine blood-brain barrier. J Cereb Blood Flow Metab (2013) 33(12):1983-92. doi:10.1038/jcbfm.2013.160

150. Esen F, Senturk E, Ozcan PE, Ahishali B, Arican N, Orhan N, et al. Intravenous immunoglobulins prevent the breakdown of the blood-brain barrier in experimentally induced sepsis. Crit Care Med (2012) 40(4):1214-20. doi:10.1097/CCM.0b013e31823779ca

151. Pashov A, Dubey C, Kaveri SV, Lectard B, Huang YM, Kazatchkine MD, et al. Normal immunoglobulin G protects against experimental allergic encephalomyelitis by inducing transferable $\mathrm{T}$ cell unresponsiveness to myelin basic protein. Eur J Immunol (1998) 28(6):1823-31. doi:10.1002/ (SICI)1521-4141(199806)28:06<1823::AID-IMMU1823>3.0.CO;2-F

152. Ephrem A, Chamat S, Miquel C, Fisson S, Mouthon L, Caligiuri G, et al. Expansion of CD4+ CD25+ regulatory T cells by intravenous immunoglobulin: a critical factor in controlling experimental autoimmune encephalomyelitis. Blood (2008) 111(2):715-22. doi:10.1182/blood-2007-03-079947

153. Nakahara J, Aiso S. Fc receptor-positive cells in remyelinating multiple sclerosis lesions. J Neuropathol Exp Neurol (2006) 65(6):582-91. doi:10.1097/00005072-200606000-00006

154. Bayry J, Hartung H-P, Kaveri SV. IVIg for relapsing-remitting multiple sclerosis: promises and uncertainties. Trends Pharmacol Sci (2015) 36(7):419-21. doi:10.1016/j.tips.2015.04.012

155. Komine-Kobayashi M, Chou N, Mochizuki H, Nakao A, Mizuno Y, Urabe T. Dual role of Fcgamma receptor in transient focal cerebral ischemia in mice. Stroke (2004) 35(4):958-63. doi:10.1161/01.STR.0000120321.30916.8E

156. Widiapradja A, Santro T, Basta M, Sobey CG, Manzanero S, Arumugam TV. Intravenous immunoglobulin (IVIg) provides protection against endothelial cell dysfunction and death in ischemic stroke. Exp Transl Stroke Med (2014) 6(1):7. doi:10.1186/2040-7378-6-7

157. Lapointe BM, Herx LM, Gill V, Metz LM, Kubes P. IVIg therapy in brain inflammation: etiology-dependent differential effects on leucocyte recruitment. Brain (2004) 127(Pt 12):2649-56. doi:10.1093/brain/awh297

158. Lok KZ, Basta M, Manzanero S, Arumugam TV. Intravenous immunoglobulin (IVIg) dampens neuronal toll-like receptor-mediated responses in ischemia. J Neuroinflammation (2015) 12(1):73. doi:10.1186/s12974-0150294-8

159. D’Ambrosio AL, Pinsky DJ, Connolly ES. The role of the complement cascade in ischemia/reperfusion injury: implications for neuroprotection. Mol Med (2001) 7(6):367-82.

160. Xu C, Poirier B, Duong Van Huyen JP, Lucchiari N, Michel O, Chevalier J, et al. Modulation of endothelial cell function by normal polyspecific human intravenous immunoglobulins: a possible mechanism of action in vascular diseases. Am J Pathol (1998) 153(4):1257-66. doi:10.1016/ S0002-9440(10)65670-2

161. Suzuki Y, Nakano Y, Mishiro K, Takagi T, Tsuruma K, Nakamura M, et al. Involvement of mincle and Syk in the changes to innate immunity after ischemic stroke. Sci Rep (2013) 3:3177. doi:10.1038/srep03177

162. Berezovskaya $\mathrm{O}$, Maysinger $\mathrm{D}$, Fedoroff $S$. Colony stimulating factor- 1 potentiates neuronal survival in cerebral cortex ischemic lesion. Acta Neuropathol (1996) 92(5):479-86. doi:10.1007/s004010050550

163. Lalancette-Hébert M, Gowing G, Simard A, Weng YC, Kriz J. Selective ablation of proliferating microglial cells exacerbates ischemic injury in the brain. J Neurosci (2007) 27(10):2596-605. doi:10.1523/JNEUROSCI.5360-06.2007

164. De I, Nikodemova M, Steffen MD, Sokn E, Maklakova VI, Watters JJ, et al. CSF1 overexpression has pleiotropic effects on microglia in vivo. Glia (2014) 62(12):1955-67. doi:10.1002/glia.22717

165. Tunik S, Aluclu MU, Acar A, Akkoc H, Guzel A, Alabalik U, et al. The effects of intravenous immunoglobulin on cerebral ischemia in rats: an experimental study. Toxicol Ind Health (2016) 32(2):229-34. doi:10.1177/0748233713498461 
166. Lok KZ, Manzanero S, Arumugam TV. Neuronal low-density lipoprotein receptor-related protein 1 (LRP1) enhances the anti-apoptotic effect of intravenous immunoglobulin (IVIg) in ischemic stroke. Brain Res (2016) 1644:192-202. doi:10.1016/j.brainres.2016.05.023

167. Rosenbaum DM, Gupta G, D’Amore J, Singh M, Weidenheim K, Zhang $\mathrm{H}$, et al. Fas (CD95/APO-1) plays a role in the pathophysiology of focal cerebral ischemia. J Neurosci Res (2000) 61:686-92. doi:10.1002/1097-4547(20000915)61:6<686::AID-JNR12>3.0.CO;2-7

168. Tzekou A, Fehlings MG. Treatment of spinal cord injury with intravenous immunoglobulin G: preliminary evidence and future perspectives. J Clin Immunol (2014) 34(Suppl 1):S132-8. doi:10.1007/s10875-014-0021-8

169. Gok B, Sciubba DM, Okutan O, Beskonakli E, Palaoglu S, Erdamar H, et al. Immunomodulation of acute experimental spinal cord injury with human immunoglobulin G. J Clin Neurosci (2009) 16(4):549-53. doi:10.1016/j. jocn.2008.04.024

170. Nguyen DH, Cho N, Satkunendrarajah K, Austin JW, Wang J, Fehlings MG. Immunoglobulin G (IgG) attenuates neuroinflammation and improves neurobehavioral recovery after cervical spinal cord injury. J Neuroinflammation (2012) 9(1):224. doi:10.1186/1742-2094-9-224

171. Corps KN, Roth TL, McGavern DB. Inflammation and neuroprotection in traumatic brain injury. JAMA Neurol (2015) 72(3):355-62. doi:10.1001/ jamaneurol.2014.3558

172. Knoblach SM, Faden AI. Administration of either anti-intercellular adhesion molecule-1 or a nonspecific control antibody improves recovery after traumatic brain injury in the rat. J Neurotrauma (2002) 19(9):1039-50. doi:10.1089/089771502760341956

173. Jeong S, Lei B, Wang H, Dawson HN, James ML. Intravenous immunoglobulin $\mathrm{G}$ improves neurobehavioral and histological outcomes after traumatic brain injury in mice. J Neuroimmunol (2014) 276(1-2):112-8. doi:10.1016/j. jneuroim.2014.08.626

174. Cengiz SL, Erdi MF, Avunduk MC, Tosun M, Ustün ME, Gökce R, et al. The role of intravenous immunoglobulin in the treatment of cerebral vasospasm induced by subarachnoid haemorrhage: an experimental study. Brain Injury (2011) 25(10):965-71. doi:10.3109/02699052.2011.589793
175. Ceppa EP, Fuh KC, Bulkley GB. Mesenteric hemodynamic response to circulatory shock. Curr Opin Crit Care (2003) 9(2):127-32. doi:10.1097/ 00075198-200304000-00008

176. Anderson J, Fleming SD, Rehrig S, Tsokos GC, Basta M, Shea-Donohue T. Intravenous immunoglobulin attenuates mesenteric ischemia-reperfusion injury. Clin Immunol (2005) 114(2):137-46. doi:10.1016/j.clim.2004.08.018

177. Giakoustidis D, Papageorgiou G, Kostopoulou E, Iliadis S, Giakoustidis A, Kontos N, et al. High dose intravenous immunoglobulin G pretreatment: effect on lipid peroxidation and reperfusion injury to the liver. World J Surg (2003) 27(12):1300-5. doi:10.1007/s00268-003-6980-1

178. Elkayam O, Paran D, Milo R, Davidovitz Y, Almoznino-Sarafian D, Zeltser D, et al. Acute myocardial infarction associated with high dose intravenous immunoglobulin infusion for autoimmune disorders. A study of four cases. Ann Rheum Dis (2000) 59(1):77-80. doi:10.1136/ard. 59.1.77

179. Ohlsson A, Lacy JB. Intravenous immunoglobulin for preventing infection in preterm and/or low-birth-weight infants. Cochrane Database Syst Rev (2001) 2:CD000361. doi:10.1002/14651858.CD000361

180. Werdan K, Pilz G, Bujdoso O, Fraunberger P, Neeser G, Schmieder RE, et al. Score-based immunoglobulin G therapy of patients with sepsis: the SBITS study. Crit Care Med (2007) 35(12):2693-701. doi:10.1097/01. CCM.0000295426.37471.79

Conflict of Interest Statement: The authors declare that the research was conducted in the absence of any commercial or financial relationships that could be construed as a potential conflict of interest.

Copyright (c) 2017 Thom, Arumugam, Magnus and Gelderblom. This is an open-access article distributed under the terms of the Creative Commons Attribution License (CC BY). The use, distribution or reproduction in other forums is permitted, provided the original author(s) or licensor are credited and that the original publication in this journal is cited, in accordance with accepted academic practice. No use, distribution or reproduction is permitted which does not comply with these terms. 